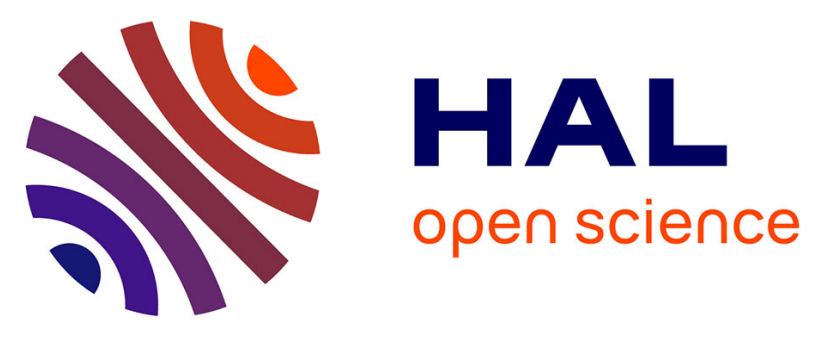

\title{
Hypoxia and succinate antagonize 2-deoxyglucose effects on glioblastoma
}

\author{
Francesca Pistollato, Sara Abbadi, Elena Rampazzo, Giampietro Viola, \\ Alessandro Della Puppa, Lucia Cavallini, Chiara Frasson, Luca Persano, \\ David M. Panchision, Giuseppe Basso
}

\section{To cite this version:}

Francesca Pistollato, Sara Abbadi, Elena Rampazzo, Giampietro Viola, Alessandro Della Puppa, et al.. Hypoxia and succinate antagonize 2-deoxyglucose effects on glioblastoma. Biochemical Pharmacology, 2010, 80 (10), pp.1517. 10.1016/j.bcp.2010.08.003 . hal-00626232

\section{HAL Id: hal-00626232 \\ https://hal.science/hal-00626232}

Submitted on 24 Sep 2011

HAL is a multi-disciplinary open access archive for the deposit and dissemination of scientific research documents, whether they are published or not. The documents may come from teaching and research institutions in France or abroad, or from public or private research centers.
L'archive ouverte pluridisciplinaire HAL, est destinée au dépôt et à la diffusion de documents scientifiques de niveau recherche, publiés ou non, émanant des établissements d'enseignement et de recherche français ou étrangers, des laboratoires publics ou privés. 


\section{Accepted Manuscript}

Title: Hypoxia and succinate antagonize 2-deoxyglucose effects on glioblastoma

Authors: Francesca Pistollato, Sara Abbadi, Elena Rampazzo, Giampietro Viola, Alessandro Della Puppa, Lucia Cavallini, Chiara Frasson, Luca Persano, David M. Panchision, Giuseppe Basso

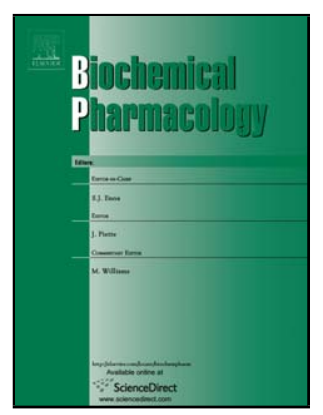

PII:

S0006-2952(10)00587-3

DOI: doi:10.1016/j.bcp.2010.08.003

Reference: BCP 10682

To appear in: $\quad B C P$

Received date: $\quad 4-6-2010$

Revised date: $\quad 3-8-2010$

Accepted date: $\quad 3-8-2010$

Please cite this article as: Pistollato F, Abbadi S, Rampazzo E, Viola G, Puppa AD, Cavallini L, Frasson C, Persano L, Panchision DM, Basso G, Hypoxia and succinate antagonize 2-deoxyglucose effects on glioblastoma, Biochemical Pharmacology (2010), doi:10.1016/j.bcp.2010.08.003

This is a PDF file of an unedited manuscript that has been accepted for publication. As a service to our customers we are providing this early version of the manuscript. The manuscript will undergo copyediting, typesetting, and review of the resulting proof before it is published in its final form. Please note that during the production process errors may be discovered which could affect the content, and all legal disclaimers that apply to the journal pertain. 


\section{HYPOXIA AND SUCCINATE ANTAGONIZE 2-DEOXYGLUCOSE EFFECTS ON GLIOBLASTOMA}

Francesca Pistollato $^{1 \dagger}$, Sara Abbadi ${ }^{1 \dagger}$, Elena Rampazzo ${ }^{1}$, Giampietro Viola ${ }^{1 *}$, Alessandro Della Puppa ${ }^{2}$, Lucia Cavallini ${ }^{3}$, Chiara Frasson ${ }^{1}$, Luca Persano $^{1}$, David M. Panchision ${ }^{4}$ and Giuseppe Basso ${ }^{1}$.

${ }^{I}$ Hemato-Oncology Laboratory, Department of Pediatrics, University of Padova, Italy

${ }^{2}$ Department of Neurosurgery, University of Padova, Italy

${ }^{3}$ Department of Biochemistry, University of Padova, Italy

${ }^{4}$ Division of Neuroscience and Basic Behavioral Science, National Institute of Mental Health, National Institutes of Health, Bethesda, MD

${ }^{\dagger}$ Equal contributing authors.

\footnotetext{
*Address correspondence to: Giampietro Viola, Hemato-Oncology Laboratory, Department of Pediatrics, University of Padova, Via Giustiniani 3, Padova 35128, Italy. Tel: +39 049 8211451; Fax: +39 049 8211462; E-mail: giampietro.viola.1@ unipd.it
} 


\begin{abstract}
Glioblastoma multiforme (GBM) are highly proliferative brain tumors characterized by a hypoxic microenvironment which controls GBM stem cell maintenance. Tumor hypoxia promotes also elevated glycolytic rate, thus limiting glucose metabolism is a potential approach to inhibit tumor growth. Here we investigate the effects mediated by 2deoxyglucose (2-DG), a glucose analogue, on primary GBM-derived cells maintained under hypoxia. Our results indicate that hypoxia protects GBM cells from the apoptotic effect elicited by 2-DG, which raises succinate dehydrogenase activity thus promoting succinate level decrease. As a consequence hypoxia inducible factor-1 $\alpha$ (HIF-1 $\alpha)$ degradation occurs and this induces GBM cells to acquire a neuronal committed phenotype. By adding succinate these effects are reverted, as succinate stabilizes HIF-1 $\alpha$ and increases GBM stem cell fraction particularly under hypoxia, thus preserving the tumor stem cell niche.

2-DG inhibits anaerobic glycolysis altering GBM cell phenotype by forcing tumor cells into mitochondrial metabolism and by inducing differentiation.
\end{abstract}

Keywords: 2-deoxyglucose; Hypoxia; Hypoxia Inducible Factor-1 $\alpha$; proline hydroxylase 2; GBM differentiation.

\footnotetext{
Abbreviations.

GBM, glioblastoma multiforme; BMP2, bone morphogenetic protein2; HIF-1 $\alpha$, hypoxia inducible factor $1 \alpha$; PHD2, Proline hydroxylase2; SDH, succinate dehydrogenase
} 


\section{Introduction}

Brain tumors and particularly glioblastoma multiforme (GBM) are highly proliferative tumors characterized by a hypoxic microenvironment. Recent literature shows that this hypoxic microenvironment correlates with tumor aggressiveness [1-3] and over-activity of hypoxia inducible factor-1 $\alpha$ (HIF-1 $\alpha)$ [4] is implicated in tumor progression and in the maintenance of a de-differentiated (i.e. stem) tumor cell phenotype [3]. Particularly, HIF-1 $\alpha$ has been found to contribute to a differentiation defect in malignant gliomas [5], even following exogenous bone morphogenetic protein2 (BMP2) treatment, known to induce glial commitment in GBM [6-8]. These evidences shed new light on the differentiation therapy of solid tumors by HIF-1 $\alpha$ targeting. Hypoxia has a role in normal physiological responses, such as carotid body growth and generation of new neural crest derived glomus cells [9], and angiogenesis [10]. It is implicated in the regulation of several developmentally important signaling pathways, such as Notch [11] and BMP pathways [7], as well as glucose metabolism [12]. Moreover, hypoxia alters cancer cells metabolism by increasing tumor anaerobic glycolysis and reducing mitochondrial activity [13]. Particularly SDH, the enzyme complex II bound to the inner mitochondrial membrane that converts succinate to fumarate via FAD reduction to FADH2, has been found inactive in some solid tumors [14]. This has been described as a key event leading to the accumulation of intra-cytoplasmic succinate and reactive oxygen species (ROS) causative of the "pseudo-hypoxic" effect, a major tumorrelated hallmark, characterized by the activation of HIF even under normoxia $[14,15]$. As intra-tumoral hypoxia increases glycolytic activity in many types of cancer, including GBM, limiting glucose uptake or glucose metabolism is a promising therapeutic approach for cancer treatment $[16,17]$ in order to reduce tumor growth as shown in animal models [18]. 2deoxyglucose (2-DG) is a glucose analogue which is converted by hexokinase to phosphorylated 2-DG, inhibiting glycolysis. Inhibition of glycolysis by phosphorylated 2- 
DG, 2-DG-6-phosphate, is thought to occur via inhibition of hexokinase and phosphohexoisomerase $[19,20]$ 2-DG is effective in several mouse tumor models, particularly in combination therapy [17]. Indeed, metformin, a widely used antidiabetic agent, has been seen to exert antitumoral and antiproliferative action in prostate cancer cells, especially when used in combination with 2-DG [21]. Moreover, earlier studies have shown that 2-DG significantly enhances the cytotoxic effects of anticancer agents like topoisomerase inhibitors and a radiomimetic drug (bleomycin) in established human tumor cell lines. Also, it has been shown that 2-DG can be used as a modulator of radiation response $[22,23]$. These studies demonstrate that targeting carbohydrate metabolism may be an effective therapeutic approach. Here we investigated how 2-DG affects primary GBM-derived cells growth, by promoting differentiation and an increase in SDH activity, leading to HIF-1 $\alpha$ degradation. Addition of succinate and preserving cells in a hypoxic microenvironment limit 2-DG effects by maintaining GBM in an undifferentiated status. Finally, our results unravel a novel mechanistic control on GBM cell metabolism and phenotype by 2-DG, succinate and oxygen tension.

\section{Materials and Methods}

\subsection{Isolation and gas-controlled expansion of cells}

Under institutional-approved protocols, tissue samples were collected from patients and neonates after written informed consent. Neonatal brain subventricular zone (SVZ) tissue was obtained at the Children's Hospital of Orange County, USA, under the auspices of the protocol for the National Human Neural Stem Cell Resource (NHNSCR). Adult GBM samples were obtained at the Padova Academic Hospital, under the auspices of the protocol for the acquisition of human brain tissues obtained from the Ethical Committee board of the 
University of Padova. Tumor and non-tumor patients characteristics are described in Table S1 (see Supplementary Information).

We dissociated and cultured cells as previously described [7]. Briefly, cells were cultured in control medium consisted of HAM'S-F12/DME with $25 \mathrm{mM}$ glucose, (Irvine Scientific, Santa Ana, CA), BIT9500, 10\%, as serum substitute (Stem Cell Technologies, Milano, Italy). For continuous expansion, one-half of the medium was replaced every day and cells were passaged every 7-10 days using TrypLE (Invitrogen, Carlsbad, CA) to dissociate them. Cells were not cultured for more than 8 passages in vitro in order to avoid long term culture related effects. Cell viability was evaluated by trypan blue exclusion. For low glucose experiments, cells were cultured in DMEM/F12, glucose-free, (Gibco BRL, Milano, Italy) with BIT9500 (10\%), for a final glucose concentration of $2.5 \mathrm{mM}$. Two different glucose concentrations were established by adding D-glucose (12.5 and $25 \mathrm{mM}$ final concentration). In experimental groups 2-deoxyglucose (2-DG) (Sigma, Milano, Italy) was added to a final concentration of 12.5 or $25 \mathrm{mM}$ as reported in literature $[24,25]$. Cells were maintained in an atmosphere of 5\% carbon dioxide and 2\% (Ruskinn C300, Ruskinn Technology Ltd, Bridgend, UK) or 20\% oxygen balanced with nitrogen [7]. In some experiments, esterificated diethyl-succinate (5 mM, Sigma-Aldrich, Milano, Italy) or pyruvate (1 mM, Sigma-Aldrich, Milano, Italy) were added for $18 \mathrm{hr}$. Pyruvate, the physiological substrate of pyruvate dehydrogenase (PDH), was used to confirm specificity of antibody specific for PDH E1 $\alpha$.

\subsection{Immunocytochemistry}

Cells were fixed in cold 4\% paraformaldehyde for $15 \mathrm{~min}$, rinsed and stored prior to analysis. Primary antibody staining was performed for nestin (mouse, 1:200, Millipore, Billerica, MA), glial fibrillary acidic protein (GFAP, mouse, 1:1000, Sigma-Aldrich, Milano, Italy), $\beta$-IIItubulin (mouse, monoclonal Tuj-1, 1:1000, Covance, Milano, Italy). After incubation, cells 
were washed and incubated with species-specific secondary antibodies conjugated to Alexa dyes (1:2000, Invitrogen, Milano, Italy). Cells were counterstained with DAPI (1:10000, Sigma-Aldrich, Milano, Italy) to measure total cell number. Staining was visualized by epifluorescence (Nikon Eclipse 80i, Melville, NY, USA) and images compiled for figures using Adobe Illustrator (Adobe, San Jose, CA).

\subsection{CD133, CD90, cell cycle and Annexin-V/Propidium Iodide analyses}

Cells $\left(2 \times 10^{5}\right.$ cells $\left./ \mathrm{ml}\right)$ were incubated with anti-human CD133 (clone AC133/2, PE conjugated, (Miltenyi Biotec, Bologna, Italy) as described in [26] and anti-human CD90 clone 5E10, FITC conjugated, ( BioLegend, Milano, Italy). Viability was assessed by adding 7-amino-actinomycin-D (7-AAD, $50 \mathrm{ng} / \mathrm{ml}$, BD Biosciences, Milano, Italy) prior to analysis. Cells were analyzed on a Cytomics FC 500 flow cytometer (Beckman Coulter, Milano, Italy). Relative percentages of different subpopulations were calculated based on live gated cells. Unlabeled cells and cells incubated with appropriate isotypic control antibodies were first acquired to ensure labeling specificity. For cell cycle phase analysis, cells were incubated with $\mathrm{BrdU}$ ( $1 \mathrm{mM}, \mathrm{BD}$, Milano, Italy) for $45 \mathrm{~min}$ then washed and prepared for analysis as directed (BrdU Flow Kit Staining Protocol, BD, Milano, Italy). Analysis of apoptosis was performed as recommended by using the Annexin Fluo kit (Roche Biochemicals, Milano, Italy).

\subsection{Mitochondrial membrane potential, reactive oxygen species (ROS) and GSH analyses}

The mitochondrial membrane potential was measured with the lipophilic cation 5,5',6,6'tetrachlo-1,1',3,3'-tetraethylbenzimidazol-carbocyanine (JC-1, Invitrogen, Milano, Italy), as described in [27], a fluorescent probe known to selectively enter into the mitochondria and used to measure changes in mitochondrial membrane potential $\left(\Delta \psi_{\mathrm{mt}}\right)$. JC-1 forms aggregates (red color) at higher potential and monomers (green color) at low membrane potential. To 
ensure JC-1 effectiveness GBM-derived cells have been pretreated with valinomycin $(1 \mu \mathrm{M}$, Sigma-Aldrich, Milano, Italy), facilitating mitochondrial membrane potential depolarization (not shown). The production of ROS was measured by flow cytometry using hydrohethidine (HE) (Invitrogen, Milano, Italy) [27]. Analysis of total GSH level was measured by using monobromobimane (mBrB), (Invitrogen, Milano, Italy) $(50 \mu \mathrm{M})[28,29]$ and chloromethyldichlorofluorescein diacetate (CM-DCFDA) (5 $\mu \mathrm{M}$, Invitrogen, Milano Italy), preincubating cells for 15 and $30 \mathrm{~min}$ at $37^{\circ} \mathrm{C}$ respectively prior to analysis.

\subsection{Western blot analyses}

Total protein extracts were isolated in lysis buffer prepared as follows: TPER Reagent (Pierce, Milano, Italy), $\mathrm{NaCl} 300 \mathrm{mM}$, orthovanadate $1 \mathrm{mM}$ (Sigma, Milano, Italy), AEBSF 2 mM (PEFABLOC, Roche Biochemicals, Milano, Italy), Aprotinin $1 \mu \mathrm{g} / \mathrm{mL}$ (Sigma-Aldrich, Milano, Italy), Pepstatin-A $5 \mu \mathrm{g} / \mathrm{ml}$ (Sigma-Aldrich, Milano, Italy) and Leupeptin $1 \mu \mathrm{g} / \mathrm{ml}$ (Sigma-Aldrich, Milano, Italy). Equal amounts of protein $(10 \mu \mathrm{g})$ were resolved using SDSPAGE gels and transferred to PVDF Hybond-p membrane (GE Healthcare, Catania, Italy). Membranes were blocked with I-blockTM Blocking (Tropix, Applied Biosystem, Monza, Italy) for at least $2 \mathrm{hr}$ under rotation at room temperature. Membranes were then incubated with primary antibodies against HIF-1 $\alpha$ (mouse, 1:250, BD Biosciences, Milano, Italy), HIF$2 \alpha$ (mouse, 1:250, Novus Biologicals, Milano, Italy), PHD2 (goat, 1:300, Santa Cruz, Santa Cruz, CA, USA), p21 ${ }^{\text {cip1 }}$ (mouse, 1:1000, Sigma-Aldrich, Milano, Italy), Bcl-2, Bcl-XL, PARP, (all rabbit, 1:1000, Cell Signaling, Milano, Italy), phosphorylated PDH E1 $\alpha$ serine 293 (rabbit, 1:5000, Novus Biologicals, Milano, Italy), total PDH E1 $\alpha$ subunit $(1: 1000$, Invitrogen, Carlsbad, CA, USA) or $\beta$-actin (mouse, 1:10000, Sigma-Aldrich, Milano, Italy) for $2 \mathrm{hr}$. Membranes were next incubated with peroxidase-labeled goat anti-rabbit IgG (1:100000, Sigma-Aldrich, Milano, Italy), peroxidase-labeled goat anti-mouse IgG 
(1:100000, Sigma-Aldrich, Milano, Italy) or peroxidase-labeled donkey anti-goat IgG (1:100000, Santa Cruz, Santa Cruz, CA, USA) for $60 \mathrm{~min}$. All membranes were visualized using ECL Advance (GE Healthcare, Catania, Italy) and exposed to Hyperfilm MP (GE Healthcare, Catania, Italy).

\subsection{Lactate Assay}

Extracellular lactate measurement was performed using the Lactate Assay Kit, (BioVision, Torino, Italy) kindly provided by Dr. Alberto Burlina (University of Padova), following the manufacturer instructions.

\subsection{Succinate dehydrogenase activity}

To evaluate aerobic metabolism succinate dehydrogenase (SDH) activity has been measured, since enzyme activity is considered an indicator of tricarboxylic acid (TCA) cycle activity. To measure SDH activity, we used the methods described by Levine et al. with little modifications [30]. Briefly, cell monolayers (not fixed) were snap-frozen at $-80^{\circ} \mathrm{C}$ for at least $1 \mathrm{hr}$ and were incubated for $20 \mathrm{~min}$ in the dark at $37^{\circ} \mathrm{C}$ in a reaction buffer containing 12.3 $\mathrm{mM}$ diethyl-succinate (Sigma, Milano, Italy), $0.2 \mathrm{mM}$ 1-methoxy-5-methylphenazine methyl sulphate (Sigma-Aldrich, Milano, Italy), $1.2 \mathrm{mM}$ nitro blue tetrazolium (NBT, SigmaAldrich, Milano, Italy) in $50 \mathrm{mM}$ Tris- $\mathrm{HCl}, \mathrm{pH}$ 7.6. We used $12.3 \mathrm{mM}$ malonate (Sigma, Milano, Italy) to test aspecific reactions, and 3-nitropropionic acid (3-NPA, $500 \mu \mathrm{M}$, SigmaAldrich, Milano, Italy), to irreversibly inactivate $\mathrm{SDH}$, as negative control. The enzyme activity is determined by measuring the formation of nitro blue diformazan (NBT-dfz) due to NBT reduction and the end product (i.e. blue cells) is visible by bright field microscopy or measured at $570 \mathrm{~nm}$, by absorption spectroscopy. 


\subsection{ATP assay}

Cells were cultured with 2 -DG for 18 or $24 \mathrm{hr}$ at either $2 \%$ or $20 \%$ oxygen, collected and counted. The ATP content per 100000 cells was determined using the CellTiter-Glo luminescent assay (Promega, Milano, Italy) according to manufacturer instruction, using a Victor $^{3 \mathrm{TM}}$ luminometer (Perkin Elmer, Milano, Italy). Data were normalized to ATP content in cells cultured with glucose at $2 \% \mathrm{O}_{2}$.

\subsection{MTT assay}

Individual wells of a 96-well tissue culture microtiter plate (Falcon, BD, Milano, Italy) were inoculated with $100 \mu \mathrm{l}$ of medium containing $5 \times 10^{3}$ of GBM cells. The plates were incubated overnight prior to the analyses. After medium removal, 2-DG was added and cells were incubated for 18 or $24 \mathrm{hr}$ at either $2 \%$ or $20 \%$ oxygen. Cell viability was assayed by the MTT [(3-(4,5-dimethylthiazol-2-yl)-2,5 diphenyl tetrazolium bromide)] test as previously described [31].

\subsection{Real-Time PCR analysis}

RNA was isolated from cells using Trizol (Invitrogen, Milano, Italy) and $1 \mu \mathrm{g}$ of total RNA reverse-transcribed using SuperScript RNAse H-Reverse Transcriptase (Invitrogen, Milano, Italy). Quantitative RT-PCR reactions were run in triplicate using Brilliant ${ }^{\circledR}$ SYBR $®$ Green QPCR Core Reagent Kit (Stratagene, La Jolla, CA, USA). Fluorescent emission was recorded in real-time (Sequence Detection System 7900HT, Applied Biosystems, Foster City, CA, USA). Gene expression profiling was completed using the comparative Ct method of relative quantification. PCR amplification conditions consisted of 50 cycles with primers annealing at $60^{\circ} \mathrm{C}$. These set of primers were used: $P H D 2$, F: 5'-GGGACATTCATTGCCTCACT-3', R: 5'-ACACATGTGGTGCTTGCTGT-3'; HIF-1 $\alpha$, F: 5'-CGTTCCTTCGATCAGTTGTC-3', 
R: 5'-TCAGTGGTGGCAGTGGTAGT-3'; beta-glucuronidase $\quad$ (GUSB), F: 5'GAAAATACGTGGTTGGAGAGCTCATT-3'， R: 5'-CCGAGTGAAGATCCCCTTTTTA3'. Primers have been designed by using the software Primer 3 (http://frodo.wi.mit.edu/primer3/input.htm) and the specificity of the primers for GUSB, HIF$1 \alpha$ and PHD2 sequences has been evaluated by using the software Human BLAT Search (http://genome.ucsc.edu/cgi-bin/hgBlat?command=start). PCR amplicons had been previously evaluated on agarose gel, and during SYBR green analyses primers dissociation curves have been checked in each run to ensure primers specificity. Relative RNA quantities were normalized to GUSB as a housekeeping gene and $2 \%$ oxygen T0 was used as the calibrating condition $(\Delta \Delta \mathrm{Ct}$ Method)

\subsection{Hypoxia Responsive Element (HRE)-luciferase reporter assay}

GBM cells were transfected using a Promega Corporation (Madison WI, USA) protocol for transient transfection of adherent cells using Effectene reagent (Qiagen, Milano, Italy). HREluciferase reporter construct used (wHRE) was kindly provided by Dr. Stefano Indraccolo (Istituto Oncologico Veneto - IRCCS, Padova, Italy). It consists of a trimerized 24-mer containing $18 \mathrm{bp}$ of sequence from the PGK promoter including the HRE (5'TGTCACGTCCTGCACGACTCTAGT, HRE) and an 8-bp linker sequence followed by a 50-bp minimal tyrosine kinase promoter in a pGL2-firefly luciferase basic Vector backbone (Promega, Madison, WI, USA) [32]. The mutant HRE (mHRE) construct used to evaluate aspecific effects, has the ACG of the HIF-1 binding site mutated to CAT, abolishing binding, as well as a point mutation that abolished a BsgI restriction site for diagnostic purposes. GBM cells were transfected either with a wHRE or with a mHRE. Along with these vectors, also a Renilla luciferase vector has been transfected in order to normalize luciferase detection (Promega, Madison, WI, USA). $12 \mathrm{hr}$ after transfection, total medium change was done and 
cells were treated with $25 \mathrm{mM}$ 2-DG, succinate $5 \mathrm{mM}$ or a combination of both for $8 \mathrm{hr}$. Finally, cells were processed and analysis of HRE-luciferase activity was performed as described (Dual-Luciferase Reporter Assay System, Promega, Madison, WI, USA) by using a plate-reading luminometer (Victor ${ }^{3 \mathrm{TM}}$, Perkin Elmer, Milano, Italy).

\subsection{Statistical analysis}

Graphs and statistical analyses were prepared using Prism 3.03 (Graph Pad, La Jolla, CA). All values were presented as mean \pm standard error of the mean (S.E.M.). Statistical significance was measured by one-way ANOVA with post-hoc Newman-Keul's test, *p < $0.05, * * \mathrm{p}<0.01, * * * \mathrm{p}<0.001$. For all graphs, an asterisk over a bracket indicates a significant difference with a variable as indicated, an asterisk over a bar indicates a significant difference between the $2 \%$ and $20 \%$ oxygen at either a particular time point or culture condition.

\section{Results}

\subsection{2-DG induces loss of GBM cell adhesive properties and decreases cell proliferation.}

It has been suggested that hypoxia is one of the major regulatory factors in the brain tumor niche, since it positively correlates with brain tumor aggressiveness, supporting the idea that hypoxia may confer a growth advantage to brain tumor stem cells [2, 3, 5, 7]. Under hypoxia cancer cell metabolism is pushed toward increased anaerobic glycolysis, which has been extensively described as a hallmark of tumor cell biology [13]. Here, we used primary cultures of adult GBM tumors to study the interaction between oxygen levels and the effects elicited by $2-D G$, thereby inducing a block of glycolysis. We evaluated cells grown in $2 \%$ oxygen, which represents the condition typically found in hypoxic solid tumors [33], versus cells that were acutely exposed to higher oxygen tension ( $20 \%$ oxygen). We found that 
addition of $25 \mathrm{mM}$ 2-DG for $18 \mathrm{hr}$, under the two oxygen tensions, induced loss of cell adhesive properties compared to GBM cells grown without 2-DG (Fig. 1A and Suppl. Fig. 1A,B). Simply decreasing the glucose medium concentration from $25 \mathrm{mM}$ to $2.5 \mathrm{mM}$, without adding 2-DG (Suppl. Fig. 1C) did not cause change of cell morphology. By adding both 2-DG and glucose in the medium (i.e. $25 \mathrm{mM}$ 2-DG $+25 \mathrm{mM}$ glucose, Suppl. Fig. 1C, or 12.5 mM 2-DG + $12.5 \mathrm{mM}$ glucose, not shown), we found that loss of cell adherence was prevented and cells showed a flat phenotype with more extensions compared to cells grown in the absence of 2-DG. Measurement of extracellular lactate was generally high in tumor cell culture medium (Fig. 1B) compared to non-tumor subventricular zone (SVZ)-derived cells (Fig. 1C), consistent with GBM cell metabolic dependence on anaerobic glycolysis. Addition of 2-DG under both oxygen tensions led to a strong extracellular lactate decrease in both GBM and SVZ-derived cells (Fig. 1B, C). Moreover, 2-DG lowered GBM cells growth (Fig. 1D), especially in cells acutely exposed to high oxygen, while SVZ cells did not undergo morphological changes (Suppl. Fig. 2A) and underwent proliferation reduction only when acutely exposed to high oxygen tension (Fig. 1E).

Analysis of GBM cell viability by trypan blue revealed no significant differences among conditions (not shown), while methyltetrazolium reduction (MTT) (Fig. 1F), indicative of extra-mitochondrial NADH and NADPH [34] occurred. Importantly, re-addition of glucose after 2-DG exposure did not recover GBM cells growth (data not shown). Also, intracellular ATP content in GBM cells, which was found higher at $20 \%$ oxygen tension consequentially to stimulated mitochondrial activity, was decreased following addition of 2-DG (Fig. 1G).

\subsection{2-DG increases succinate dehydrogenase and pyruvate dehydrogenase activity.}

We sought to investigate if 2-DG, besides determining a glycolytic block, was able to perturb mitochondrial metabolism. Thus, we analyzed succinate dehydrogenase (SDH) activity. It is 
known that SDH activation is impaired in several solid tumors, inducing the accumulation of succinate and ROS into the cytoplasm and causing strong HIF-1 $\alpha$ stabilization even in the absence of hypoxia [14]. Surprisingly, we found that addition of 2-DG increased SDH activity in GBM-derived cells, especially at $20 \%$ oxygen (Fig. 2A, B). Addition of cell permeable succinate either in presence or absence of 2-DG did not modify SDH activation state (data not shown). Notably, in SVZ-derived cells SDH activity did not change after addition of 2-DG (data not shown), confirming differences in metabolic response between non-tumor and tumor cells.

Additionally, we analyzed the phosphorylation state of pyruvate dehydrogenase E1 $\alpha$ (pPDH E1 $\alpha$ ) in order to test if addition of 2-DG induced an increase of mitochondrial metabolism. The PDH complex contributes to transforming pyruvate into acetyl-CoA, which is used in the citric acid cycle to carry out cellular respiration. The activation state of PDH is controlled by the enzyme pyruvate dehydrogenase kinase (PDK), which inhibits PDH activity by phosphorylating it using ATP [35]. We found that GBM cells maintained at 2\% oxygen had a higher level of pPDH compared to cells acutely exposed to $20 \%$ oxygen (see $\mathrm{T} 0$ at $2 \%$ and T0 at $20 \%$ oxygen in Fig. 2C), indicating inactivation of the complex and increased lactate production level under hypoxia, as confirmed in Fig. 1B. After the addition of 2-DG, a transient increase of pPDH level occurred, which decreased after $18 \mathrm{hr}$ (Fig. 2C) and $24 \mathrm{hr}$ (data not shown). Importantly, total PDH level did not significantly change following addition of 2-DG (Fig. 2C). These results, together with the observation of an increase in SDH activation after the addition of 2-DG (Fig. 2A, B) indicate a transient recovery of mitochondrial activity following addition of 2-DG.

As intracellular succinate level and ROS production are associated to SDH activity and defects of electron transfer in the respiratory chain are bound to enhanced ROS production [36], we evaluated the possible effects of 2-DG on ROS production. We found that hypoxic 
GBM-derived cells, which resulted to contain a variable but generally high percentage of ROS, underwent transient superoxide anion $\left(\mathrm{O}_{2}{ }^{-}\right)$reduction after the addition of 2-DG for 18 hr (Fig. 2D). Importantly, by adding succinate to GBM cells ROS levels were higher under both oxygen tensions and this effect was repressed by the addition of 2-DG (Fig. 2E). Conversely, significant variations of ROS content under the same conditions were not observed in SVZ-derived cells (Suppl. Fig. 2B).

The decrease in ROS may also relate to higher reduced glutathione (GSH) level. GSH is maintained in cells by reduced nicotinamide adenine dinucleotide phosphate (NADPH), which is primarily generated when glucose is metabolized by pentose phosphate pathway. By measuring total GSH level we could not find any significant change following addition of 2DG (Suppl. Fig. 3). This suggests that ROS level reduction is primarily connected to higher SDH activity (i.e. lower succinate level) rather than improved cytoplasmic radical scavenging.

\subsection{2-DG promotes HIF-1 $\alpha$ degradation in GBM cells.}

It has been previously reported in a fibrosarcoma cell line that the hypoxic accumulation of HIF-1 $\alpha$, an endogenous hypoxia marker, strongly depends on glucose availability, as shown by modulation with 2-DG[37]. Nevertheless, the molecular mechanism causing this phenomenon has not been elucidated. HIF-1 $\alpha$ is known to be chemically stabilized by hypoxia independent factors, such as mitochondrial ROS [38], $\mathrm{CoCl}_{2}, \mathrm{Fe}^{2+}$ and cytoplasmic succinate [14], all known to be cofactors and inhibitors of proline hydroxylases (PHDs) [39], which target HIF-1 $\alpha$ degradation through proteasome. Importantly, we found that HIF-1 $\alpha$ protein level was reduced by 2-DG under hypoxia, in some cases below detection level (Fig. 3A). Higher-molecular-weight isoform of HIF-1 $\alpha$, indicative of poly-ubiquitylated isoform [15], eventually occurred (Fig. 3A). In SVZ-derived cells HIF-1 $\alpha$ was rapidly reduced 
following addition of 2-DG but its recovery was visible after $18 \mathrm{hr}$ (Suppl. Fig. 2C). HIF-2 $\alpha$ has been described as a promising target for anti-GBM therapies as it has been found highly expressed in glioma stem cells [40]. We found that, oppositely to HIF-1 $\alpha$, HIF-2 $\alpha$ level was not significantly decreased by addition of 2-DG (Fig. 3A).

To explain HIF-1 $\alpha$ degradation, we tested expression of proline hydroxylase-2 (PHD2), the best described proline hydroxylase involved in HIF-1 $\alpha$ protein hydroxylation. We found that after addition of 2-DG, PHD2 protein increased under hypoxia (Fig. 3A) reaching the level observed in cells exposed to $20 \%$ oxygen. We hypothesized that 2-DG-mediated PHD2 protein increase was dependent on de novo protein synthesis. Analyses of QRT-PCR revealed that $H I F-1 \alpha$ transcript did not change after addition of 2-DG (Fig. 3B), while expression of PHD2 transcript was decreased by 2-DG (Fig. 3C), leading to exclude de novo PHD2 synthesis. Importantly, by silencing HIF-1 $\alpha$ with lentiviral vectors GBM-derived cells acquired a more differentiated phenotype, with increased endogenous BMP signalling, and eventually underwent cell death after 5-7 days, as already reported [7, 8]. Importantly, further addition of 2-DG did not promote any difference in HIF-1 $\alpha$ silenced cells (data not shown).

\subsection{Addition of succinate prevents 2-DG-mediated HIF-1 $\alpha$ degradation.}

As HIF-1 $\alpha$ stability is related to accumulation of intra-cytoplasmic succinate consequential to impaired SDH activity [14], we hypothesized that 2-DG dependent HIF-1 $\alpha$ degradation may be caused by the observed increase of SDH activity (Fig. 2A,B). To prove this hypothesis we evaluated if addition of succinate in combination with 2-DG, promoted a recovery of HIF-1 $\alpha$ protein level in GBM-derived cells. We found that HIF-1 $\alpha$ stability was recovered in 2DG/succinate cultured cells (Fig. 3D). Analysis of HIF-2 $\alpha$ did not reveal any significant change among conditions (Fig. 3D). 
We investigated if 2-DG, besides modulating HIF-1 $\alpha$ protein stability, promoted also inhibition of HIF-1 $\alpha$ transcriptional activity, by using a hypoxia responsive element (HRE)luciferase reporter construct. We found a modest reduction of HIF-1 $\alpha$ transcriptional activity under hypoxia following $8 \mathrm{hr}$ of 2-DG treatment compared to untreated GBM cells (Fig. 3E). Notably, by adding succinate together with 2-DG this reduction did not occur, and addition of succinate alone doubled HIF-1 $\alpha$ transcriptional activity (Fig. 3E).

\subsection{Hypoxia inhibits the pro-apoptotic effect caused by 2-DG in GBM-derived cells.}

We sought to investigate whether these changes of GBM metabolic profile and the observed reduction of HIF-1 $\alpha$ protein level correlated to block of cell cycle and induction of apoptosis. It has already been reported that downregulation of HIF-1 $\alpha$ suppresses tumorigenicity of renal cell carcinoma through induction of apoptosis [41] and attenuates glioma growth in vivo [42]. Analysis of cell cycle revealed that addition of 2-DG in GBM cells acutely exposed to high oxygen tension induced a modest but not significant decrease of $\mathrm{S}$ phase and a slight increase of apoptotic cells (sub G1 fraction), but these effects were not observed in hypoxia (Fig. 4A). Analysis of apoptosis by using annexin-V/propidium iodide staining (annexin-V/PI) indicated that addition of 2-DG significantly induced early apoptosis (annexin- $\mathrm{V}^{+} / \mathrm{PI}^{-}$cells) especially when GBM cells were exposed for 24 and $48 \mathrm{hr}$ to high oxygen tension (Fig. 4B). Oppositely, addition of 2-DG on SVZ-derived cells did not promote significant cell cycle changes and/or induction of apoptosis (not shown).

Apoptosis often implicates disruption of mitochondrial membrane potential $\left(\Delta \psi_{\mathrm{mt}}\right)$. We found that addition of 2-DG for 24 and $48 \mathrm{hr}$ caused reduction of $\Delta \psi_{\mathrm{mt}}$ especially when cells were exposed to $20 \%$ oxygen (Fig. 4C). Moreover, we found that anti-apoptotic proteins (Bcl-2 and Bcl-XL), involved in mitochondria controlled apoptosis, were down-regulated more rapidly by addition of 2 DG under $20 \%$ oxygen, while PARP cleavage, which is a marker of 
cells undergoing apoptosis [43], occurred earlier under the same conditions (Fig. 4D). Importantly, even though decrease of Bcl-2 and Bcl-XL proteins occurred even after $18 \mathrm{hr}$ after addition of 2-DG, percentage of early apoptotic cells (annexin- $\mathrm{V}^{+} / \mathrm{PI}^{-}$cells) increased significantly only after $48 \mathrm{hr}$ (Fig. 4B). In normal SVZ-derived cells these apoptosis-related proteins were not affected at early time points, but only after prolonged 2-DG stimulus (Suppl. Fig. 2C).

Analysis of $\mathrm{p} 21^{\text {cip } 1}$, which is related to cell cycle arrest and induction of differentiation or to cell death [44], revealed that GBM cells exposed to $20 \%$ oxygen, independently from addition of 2-DG, had a higher $\mathrm{p} 21^{\mathrm{cip} 1}$ level compared to cells maintained under hypoxia, confirming our previous report [7] (Fig. 4D). Under hypoxia addition of 2-DG slowly upregulated $\mathrm{p} 21^{\mathrm{cip} 1}$ (Fig. 4D) to level comparable to the one observed at $20 \%$ oxygen. In SVZderived cells $\mathrm{p} 21^{\text {cip1 }}$ did not change following addition of 2-DG (Suppl. Fig. 2C).

\subsection{2-DG induces neuronal commitment and addition of succinate antagonizes this effect by} reducing GBM differentiation.

HIF-1 $\alpha$ expression has been related to the maintenance of a more immature phenotype in ductal breast carcinoma and neuroblastoma [2,3], a phenomenon that has been recently described also in malignant gliomas [5,7]. As we found that addition of 2-DG within the first $18 \mathrm{hr}$ induced increase of $\mathrm{p} 21^{\mathrm{cip} 1}$, with apoptosis significantly occurring after $48 \mathrm{hr}$ (Fig. 4BD), together with HIF-1 $\alpha$ poly-ubiquitylation and degradation even under hypoxia (Fig. 3A), we evaluated if these events correlated to the acquisition of a more differentiated phenotype in live remaining GBM cells. Flow cytometric analysis of cell surface marker CD133, revealed that addition of $2-\mathrm{DG}$ promoted a decrease of $\mathrm{CD} 133^{+}$cells percentage, especially at $20 \%$ oxygen (Fig. 5A). Normal SVZ-derived cells contained a lower percentage of CD133 ${ }^{+}$ cells compared to GBM-derived cells, and addition of 2-DG analogously induced a slight 
decrease of $\mathrm{CD}_{133^{+}}$cells (Suppl. Fig. 2D). Importantly, we found that addition of succinate under hypoxia increased $\mathrm{CD} 133^{+}$cells in GBM (Fig. 5A), and this did not occur in SVZderived cells (Suppl. Fig. 2D). Addition of both 2-DG and succinate slightly prevented 2-DGmediated decrease of tumor $\mathrm{CD}_{133^{+}}$cells exposed to $20 \%$ oxygen (Fig. 5A). Another described GBM stem cell marker is CD90 [45], which we found to be highly expressed in all our GBM cell cultures. Nevertheless, only a slight decrease of $\mathrm{CD} 90^{+}$cells was observed after addition of 2-DG and succinate did not reverse this effect (Suppl. Fig. 4).

Immunocytochemical analysis on adherent remaining cells of nestin (Fig. 5B,E), indicative of undifferentiated precursors, glial fibrillary acidic protein (GFAP) (Fig. 5C,E), a marker of astroglia and their progenitors, and $\beta \mathrm{III}-$ tubulin (Fig. 5D,F), expressed in neurons and their committed progenitors, revealed that addition of 2-DG under hypoxia promoted specifically neuronal differentiation (i.e. higher $\beta$ III-tubulin ${ }^{+}$cells percentage), rather than glial commitment, with decrease in nestin ${ }^{+}$cells. In GBM cells acutely exposed to $20 \%$ oxygen a higher basal neuronal and glial commitment was visible and under this condition the addition of 2-DG did not further increase differentiation. Opposite to 2-DG effects, addition of succinate raised fraction of nestin ${ }^{+}$cells (Fig. 5B, E), lowering the percentage of $\mathrm{GFAP}^{+}$and $\beta$ III-tubulin ${ }^{+}$cells (Fig. 5C-F). Finally, addition of succinate together with 2-DG prevented 2DG mediated differentiation of GBM-derived cells (Fig. 5B-D). Altogether these data suggest that addition of 2-DG promotes induction of GBM cell differentiation and lately cell death under $20 \%$ oxygen, while maintaining cells at $2 \%$ oxygen partially inhibits these effects, preserving tumor stem cells survival, despite HIF-1 $\alpha$ degradation occurs.

\section{Discussion}

There have been increasing efforts to characterize the solid tumor microenvironment and to define which signalling molecules and metabolic responses may be disrupted in tumor cells. 
As the most primitive tumor cells share characteristics with non-tumor stem cells [46], the microenvironment that regulates stem cell self-renewal and differentiation may also play a role in the proliferation and fate of tumor cells. In particular, there is evidence that hypoxia plays a key role in normal homeostasis of stem cells [9] and in the initiation, development and aggressiveness of gliomas [47]. Accordingly, our recent report confirmed that intratumoral hypoxia drives GBM stem cells distribution [48]. Hypoxia could be crucial to recruit cancer stem-like cells, deregulating their differentiation [2,3,7] and altering their metabolism, by increasing tumor glycolytic response and reducing mitochondrial metabolism. Particularly, among mitochondrial dehydrogenases, SDH has been found inactive in some solid tumors, and this has been described as a key event leading to the accumulation of intra-cytoplasmic succinate and ROS causative of the "pseudo-hypoxic" effect. This is a major tumor-related hallmark, characterized by the activation of HIF even in the absence of hypoxia $[14,15]$. Moreover, recent reports indicate that the gene encoding isocitrate dehydrogenase-1 (IDH1), one of the enzyme of citric acid cycle which is related to HIF-1 pathway, is mutated in $80 \%$ of certain types of GBM [49-51], thus linking mitochondrial dysfunction to tumorigenesis.

2-DG, a glucose analogue that reduces intracellular utilization of glucose, inhibits glycolysis, through competitive inhibition of some glycolytic enzymes. 2-DG can affect the growth of some tumors in vivo and it has been shown to be cytotoxic in vitro [52]. In a recent work HIF-1 $\alpha$ has been shown to mediate resistance specifically to glycolytic inhibitors [53], however, the molecular mechanisms by which hypoxia may counteract 2-DG effects in brain tumor has not been so far fully elucidated. A decrease in provision of glucose (from $25 \mathrm{mM}$ to $2,5 \mathrm{mM}$ ) and also of oxygen $(2 \%)$ can be found in the internal perinecrotic/hypoxic region of the solid tumor mass compared to peripheral, relatively well-nourished regions of the tumor [54]. Thus, in this study we set our control maintaining GBM-derived cells at $2 \%$ 
oxygen and in presence of high glucose concentration. We show that inhibiting glycolisis by addition of 2-DG, induces a decrease in cell proliferation and late apoptosis in primary GBMderived cells acutely exposed to $20 \%$ oxygen, while these effects are partially inhibited by hypoxia, condition in which 2-DG addition causes GBM cell differentiation and HIF-1 $\alpha$ level reduction. Importantly, normal SVZ-derived cells are not affected by addition of 2-DG.

Degradation of HIF-1 $\alpha$ by 2-DG has been described in a previous report [37], nevertheless a molecular explanation for this effect has not been so far fully provided. Here we show that 2DG increases SDH activity, reducing ROS levels and these are reliably causative of the observed HIF-1 $\alpha$ degradation, consequentially to increased PHD2 activity. Indeed, HIF-1 $\alpha$ is known to be chemically stabilized also by hypoxia independent factors, such as ROS [38], $\mathrm{CoCl}_{2}, \mathrm{Fe}^{2+}[39]$ and cytoplasmic succinate [14]. Earlier studies have suggested that ROS produced by mitochondria are required for proper induction of HIF-1 $\alpha$ under hypoxic conditions $[55,56]$. It has been well established, that $\mathrm{Fe}^{2+}$ is an important cofactor for PHDs [39], and importantly $\mathrm{H}_{2} \mathrm{O}_{2}$, produced by mitochondria, is known to destabilize PHDs activity, either by converting $\mathrm{Fe}^{2+}$ in $\mathrm{Fe}^{3+}$ or by induction of post-transcriptional modifications of PHD2 [55]. Besides ROS acting as second messengers, impaired SDH activity and consequential intra-cytoplasmic succinate accumulation are associated to HIF-1 $\alpha$ stabilization in several cancer types [14]. We found that addition of succinate reverts 2-DG effects, promoting recovery of HIF-1 $\alpha$ protein level and transcriptional activity (i.e. HREluciferase), as well as increase of ROS levels. Besides succinate, PHDs have been shown to be regulated also by other glycolytic and citric acid cycle metabolites, such as pyruvate and oxaloacetate, that could independently modify the oxygen-sensing abilities of cells [57]. While we found that PHD2 protein level is raised by addition of 2-DG, $P H D 2$ transcription is decreased, and this is related to the observed degradation of HIF-1 $\alpha$, known to control PHD2 transcription [58]. Additionally, HIF-2 $\alpha$ has been found highly expressed in glioma stem cells 
[39], but we did not find change of HIF-2 $\alpha$ protein level following neither stimulus with 2DG, nor addition of succinate.

Importantly, HIF-1 $\alpha$ is related to maintenance of an undifferentiated cell state and inhibition of cell differentiation $[7,11]$. Particularly, HIF-1 $\alpha$ contributes to a differentiation defect in malignant gliomas [5], even following exogenous BMP2 treatment [7, 8], shedding new light on the differentiation therapy of solid tumors by HIF-1 $\alpha$ targeting. Therefore, HIF-1 $\alpha$ has become in recent years an attractive, although challenging, therapeutic target [59]. Here, we found that after addition of 2-DG, a decrease of $\mathrm{CD}_{133^{+}}$and nestin ${ }^{+}$cells and induction of neuronal differentiation occur under hypoxia, condition in which GBM cells are maintained in a less committed state [7,48]. Oppositely, addition of succinate increases GBM cell undifferentiated state, preventing the pro-differentiating effects evoked by 2-DG.

Previous reports describe that highly de-differentiated and fast-growing tumors compared to slow-growing tumors or non-tumor cells are characterized by faster glycolysis and slower oxidative phosphorylation [60-63]. Here we found that diverse mechanisms may control GBM cell phenotype: on one side addition of 2-DG and raised oxygen tension induce GBM cell commitment and eventually cell death; oppositely to these, succinate and hypoxia promote GBM immature cells maintenance (Fig. 6).

In conclusion, we show that reducing glycolysis in GBM tumor cells destabilizes cell functional and metabolic status, forcing cancer cells into a mitochondrial metabolism, as demonstrated by the activation of PDH and SDH, and promoting GBM cell differentiation. These findings improve the knowledge of GBM tumor intra- and extra-cellular microenvironment and the mechanisms by which GBM cells respond to an alteration of their metabolic state. 


\section{Competing interests}

The authors declare that they have no competing interests.

\section{Acknowledgments}

We thank Dr. Ahmed Mohyeldin for kindly providing the antibody for pPDH E1 $\alpha$, Dr. Hugo Guerrero-Cazares and Dr. Martina Pigazzi for their suggestions on the manuscript; Dr. Alberto Burlina for kindly providing the Lactate Assay Kit. This work was supported by funds from the Italian Association for the Fight against Neuroblastoma (Pensiero Project) and the Italian Association AIRC (Interregional pediatric project grant). 


\section{References}

[1] Azuma Y, Chou SC, Lininger RA, Murphy BJ, Varia MA, Raleigh JA Hypoxia and differentiation in squamous cell carcinomas of the uterine cervix: pimonidazole and involucrin. Clin Cancer Res 2003;9:4944-4952.

[2] Helczynska K, Kronblad A, Jogi A, Nilsson E, Beckman S, Landberg G, et al. Hypoxia promotes a dedifferentiated phenotype in ductal breast carcinoma in situ. Cancer Res 2003;63:1441-1444.

[3]Jogi A, Ora I, Nilsson H, Lindeheim A, Makino Y, Poellinger L, et al. Hypoxia alters gene expression in human neuroblastoma cells toward an immature and neural crestlike phenotype. Proc Natl Acad Sci U S A 2002;99:7021-7026.

[4]Smith K, Gunaratnam L, Morley M, Franovic A, Mekhail K, Lee S Silencing of epidermal growth factor receptor suppresses hypoxia-inducible factor-2-driven VHL/- renal cancer. Cancer Res 2005;65:5221-230.

[5]Lu H, Li Y, Shu M, Tang J, Huang Y, Zhou Y, et al. Hypoxia-inducible factor-1alpha blocks differentiation of malignant gliomas. FEBS J 2009;276:7291-304

[6]Piccirillo SG, Reynolds BA, Zanetti N, Lamorte G, Binda E, Broggi G, et al. Bone morphogenetic proteins inhibit the tumorigenic potential of human brain tumourinitiating cells. Nature 2006;444:761-65.

[7]Pistollato F, Chen HL, Rood BR, Zhang HZ, D'Avella D, Denaro L, et al. Hypoxia and HIF1alpha repress the differentiative effects of BMPs in high-grade glioma. Stem Cells 2009; 27:7-17.

[8]Pistollato F, Rampazzo E, Abbadi S, Della Puppa A, Scienza R, D'Avella D, et al. Molecular mechanisms of HIF-1alpha modulation induced by oxygen tension and BMP2 in glioblastoma derived cells. PLoS One 2009;4:e6206. 
[9]Pardal R, Ortega-Saenz P, Duran R, Lopez-Barneo J Glia-like stem cells sustain physiologic neurogenesis in the adult mammalian carotid body. Cell 2007;131:36477.

[10]Wong ET, Brem S Antiangiogenesis treatment for glioblastoma multiforme challenges and opportunities. J Natl Compr Canc Netw 2008; 6:515-22.

[11]Gustafsson MV, Zheng X, Pereira T, Gradin K, Jin S, Lundkvist J, et al. Hypoxia requires notch signaling to maintain the undifferentiated cell state. Dev Cell 2005; 9:617-28.

[12]Dang CV, Semenza GL Oncogenic alterations of metabolism. Trends Biochem Sci 1999;24:68-72.

[13]Hsu PP, Sabatini DM Cancer cell metabolism: Warburg and beyond. Cell 2008; $134: 703-7$

[14]King A, Selak MA, Gottlieb E Succinate dehydrogenase and fumarate hydratase: linking mitochondrial dysfunction and cancer. Oncogene 2006;25:4675-82.

[15]MacKenzie ED, Selak MA, Tennant DA, Payne LJ, Crosby S, Frederiksen CM, et al. Cell-permeating alpha-ketoglutarate derivatives alleviate pseudohypoxia in succinate dehydrogenase-deficient cells. Mol Cell Biol 2007; 27:3282-3289.

[16]Jin S, DiPaola RS, Mathew R, White E Metabolic catastrophe as a means to cancer cell death. J Cell Sci 2007;120:379-83.

[17]Zhu Z, Jiang W, McGinley JN, Thompson HJ 2-Deoxyglucose as an energy restriction mimetic agent: effects on mammary carcinogenesis and on mammary tumor cell growth in vitro. Cancer Res 2005:65:7023-30.

[18]Michels KB, Ekbom A Caloric restriction and incidence of breast cancer. JAMA 2004;291:1226-1230. 
[19]Liu X, Kim CS, Kurbanov FT, Honzatko RB, Fromm HJ Dual mechanisms for glucose 6-phosphate inhibition of human brain hexokinase. J Biol Chem 1999; 274:31155-59.

[20]Nelson CA, Wang JQ, Leav I, Crane PD The interaction among glucose transport, hexokinase, and glucose-6-phosphatase with respect to $3 \mathrm{H}$-2-deoxyglucose retention in murine tumor models. Nucl Med Biol 1996;23:533-541.

[21]Ben Sahra I, Laurent K, Giuliano S, Larbret F, Ponzio G, Gounon P, et al. Targeting cancer cell metabolism: the combination of metformin and 2-deoxyglucose induces p53-dependent apoptosis in prostate cancer cells. Cancer Res. 2010;70:2465-75.

[22] Singh D, Banerji AK, Dwarakanath BS, Tripathi RP, Gupta JP, Mathew TL, et al. Optimizing cancer radiotherapy with 2-deoxy-d-glucose dose escalation studies in patients with glioblastoma multiforme. Strahlenther Onkol 2005;181:507-14.

[23] Gupta S, Farooque A, Adhikari JS, Singh S, Dwarakanath BS. Enhancement of radiation and chemotherapeutic drug responses by 2-deoxy-D-glucose in animal tumors. J Cancer Res Ther 2009;5 Suppl 1:S16-20

[24]Hunter AJ, Blekkenhorst GH The effects of 2-deoxyglucose and amino-oxyacetic acid on the radiation response of mammalian cells in vitro. Int J Radiat Biol 1998; $73: 311-24$

[25]Jelluma N, Yang X, Stokoe D, Evan GI, Dansen TB, Haas-Kogan DA Glucose withdrawal induces oxidative stress followed by apoptosis in glioblastoma cells but not in normal human astrocytes. Mol Cancer Res 2006;4:319-30.

[26]Panchision DM, Chen HL, Pistollato F, Papini D, Ni HT, Hawley TS Optimized flow cytometric analysis of central nervous system tissue reveals novel functional relationships among cells expressing CD133, CD15, and CD24. Stem Cells 2007; 25:1560-70. 
[27]Viola G, Salvador A, Vedaldi D, Fortunato E, Disaro S, Basso G, et al. Induction of apoptosis by photoexcited tetracyclic compounds derivatives of benzo[b]thiophenes and pyridines. J Photochem Photobiol B 2006;82:105-16.

[28]Chow S, Hedley D Flow cytometric determination of glutathione in clinical samples. Cytometry 1995;21:68-71.

[29]Rice GC, Bump EA, Shrieve DC, Lee W, Kovacs M Quantitative analysis of cellular glutathione by flow cytometry utilizing monochlorobimane: some applications to radiation and drug resistance in vitro and in vivo. Cancer Res 1986;46:6105-10.

[30]Levine S, Gregory C, Nguyen T, Shrager J, Kaiser L, Rubinstein N, Dudley G Bioenergetic adaptation of individual human diaphragmatic myofibers to severe COPD. J Appl Physiol 2002, 92:1205-13.

[31]Mosmann T Rapid colorimetric assay for cellular growth and survival: application to proliferation and cytotoxicity assays. J Immunol Methods 1983;65:55-63.

[32]Arsham AM, Plas DR, Thompson CB, Simon MC Phosphatidylinositol 3-kinase/Akt signaling is neither required for hypoxic stabilization of HIF-1 alpha nor sufficient for HIF-1-dependent target gene transcription. J Biol Chem 2002;277:15162-170.

[33]Ljungkvist AS, Bussink J, Kaanders JH, van der Kogel AJ Dynamics of tumor hypoxia measured with bioreductive hypoxic cell markers. Radiat Res 2007;167:12745.

[34]Berridge MV, Tan AS Characterization of the cellular reduction of 3-(4,5dimethylthiazol-2-yl)-2,5-diphenyltetrazolium bromide (MTT): $\quad$ subcellular localization, substrate dependence, and involvement of mitochondrial electron transport in MTT reduction. Arch Biochem Biophys 1993;303:474-482. 
[35]McFate T, Mohyeldin A, Lu H, Thakar J, Henriques J, Halim ND, et al. Pyruvate dehydrogenase complex activity controls metabolic and malignant phenotype in cancer cells. J Biol Chem 2008;283:22700-708.

[36]Lenaz $\mathrm{G}$ The mitochondrial production of reactive oxygen species: mechanisms and implications in human pathology. IUBMB Life 2001;52:159-64.

[37]Staab A, Loffler J, Said HM, Katzer A, Beyer M, Polat B Modulation of glucose metabolism inhibits hypoxic accumulation of hypoxia-inducible factor-1alpha (HIF1alpha). Strahlenther Onkol 2007;183:366-73.

[38]Taylor CT Mitochondria and cellular oxygen sensing in the HIF pathway. Biochem J 2008;409:19-26.

[39]Kang GS, Li Q, Chen H, Costa M Effect of metal ions on HIF-1alpha and Fe homeostasis in human A549 cells. Mutat Res 2006;610:48-55.

[40]Li Z, Bao S, Wu Q, Wang H, Eyler C, Sathornsumetee S, et al. Hypoxia-inducible factors regulate tumorigenic capacity of glioma stem cells. Cancer Cell 2009;15:50113.

[41] Xu K, Ding Q, Fang Z, Zheng J, Gao P, Lu Y,et al. Silencing of HIF-1alpha suppresses tumorigenicity of renal cell carcinoma through induction of apoptosis. Cancer Gene Ther 2010;17:212-22.

[42] Gillespie DL, Whang K, Ragel BT, Flynn JR, Kelly DA, Jensen RL. Silencing of hypoxia inducible factor-1alpha by RNA interference attenuates human glioma cell growth in vivo. Clin Cancer Res. 2007; 13:2441-8

[43]Oliver FJ, de la Rubia G, Rolli V, Ruiz-Ruiz MC, de Murcia G, Murcia JM Importance of poly(ADP-ribose) polymerase and its cleavage in apoptosis. Lesson from an uncleavable mutant. J Biol Chem 1998;273:33533-39. 
[44]Gartel AL p21(WAF1/CIP1) and cancer: a shifting paradigm? Biofactors 2009; $35: 161-164$

[45]Kang MK, Kang SK Tumorigenesis of chemotherapeutic drug-resistant cancer stemlike cells in brain glioma. Stem Cells Dev 2007;16:837-47.

[46]Singh SK, Clarke ID, Terasaki M, Bonn VE, Hawkins C, Squire J, et al. Identification of a cancer stem cell in human brain tumors. Cancer Res 2003;63:582128.

[47]Diabira S, Morandi X Gliomagenesis and neural stem cells: Key role of hypoxia and concept of tumor "neo-niche". Med Hypotheses 2008;70:96-104.

[48] Pistollato F, Abbadi S, Rampazzo E, Persano L, Puppa AD, Frasson C, et al. Intratumoral Hypoxic Gradient Drives Stem Cells Distribution and MGMT Expression in Glioblastoma. Stem Cells 2010;28:851-62

[49]Parsons DW, Jones S, Zhang X, Lin JC, Leary RJ, Angenendt P, et al. An integrated genomic analysis of human glioblastoma multiforme. Science 2008;321:1807-1812.

[50]Pollard PJ, Ratcliffe PJ Cancer. Puzzling patterns of predisposition. Science 2009; 324:192-194.

[51]Zhao S, Lin Y, Xu W, Jiang W, Zha Z, Wang P, et al. Glioma-derived mutations in IDH1 dominantly inhibit IDH1 catalytic activity and induce HIF-1alpha. Science 2009;324:261-265.

[52]Aft RL, Lewis JS, Zhang F, Kim J, Welch MJ Enhancing targeted radiotherapy by copper(II)diacetyl- bis(N4-methylthiosemicarbazone) using 2-deoxy-D-glucose. Cancer Res 2003;63:5496-504.

[53]Maher JC, Wangpaichitr M, Savaraj N, Kurtoglu M, Lampidis TJ Hypoxia-inducible factor-1 confers resistance to the glycolytic inhibitor 2-deoxy-D-glucose. Mol Cancer Ther 2007;6:732-41. 
[54]Dearling JL, Qureshi U, Begent RH, Pedley RB Combining radioimmunotherapy with antihypoxia therapy 2-deoxy-D-glucose results in reduction of therapeutic efficacy. Clin Cancer Res 2007;13:1903-10.

[55]Bell EL, Klimova TA, Eisenbart J, Moraes CT, Murphy MP, Budinger GR,et al. The Qo site of the mitochondrial complex III is required for the transduction of hypoxic signaling via reactive oxygen species production. J Cell Biol 2007;177:1029-36.

[56]Chandel NS, McClintock DS, Feliciano CE, Wood TM, Melendez JA, Rodriguez AM, et al. Reactive oxygen species generated at mitochondrial complex III stabilize hypoxia-inducible factor-1alpha during hypoxia: a mechanism of $\mathrm{O}_{2}$ sensing. J Biol Chem 2000;275:25130-138.

[57]Dalgard CL, Lu H, Mohyeldin A, Verma A Endogenous 2-oxoacids differentially regulate expression of oxygen sensors. Biochem J 2004;380:419-24.

[58]Metzen E, Stiehl DP, Doege K, Marxsen JH, Hellwig-Burgel T, Jelkmann W Regulation of the prolyl hydroxylase domain protein 2 (phd2/egln-1) gene: identification of a functional hypoxia-responsive element. Biochem J 2005;387:71117.

[59]Poon E, Harris AL, Ashcroft M Targeting the hypoxia-inducible factor (HIF) pathway in cancer. Expert Rev Mol Med 2009;11:e26.

[60]Krieg RC, Knuechel R, Schiffmann E, Liotta LA, Petricoin EF, 3rd, Herrmann PC Mitochondrial proteome: cancer-altered metabolism associated with cytochrome c oxidase subunit level variation. Proteomics 2004;4:2789-95.

[61]Moreno-Sanchez R, Rodriguez-Enriquez S, Marin-Hernandez A, Saavedra E Energy metabolism in tumor cells. FEBS J 2007;274:1393-418.

[62]Pedersen PL: Tumor mitochondria and the bioenergetics of cancer cells. Prog Exp Tumor Res 1978;22:190-274. 
1

2

3

4

5

6

7

8

9

10

11

12

13

14

15

16

17

18

19

20

21

22

23

24

25

26

27

28

29

30

31

32

33

34

35

36

37

38

39

40

41

42

43

44

45

46

47

48

49

50

51

52

53

54

55

56

57

58

59

60

61

62

63

[63]Ristow M Oxidative metabolism in cancer growth. Curr Opin Clin Nutr Metab Care 2006;9:339-345. 


\section{Figure legends}

Figure 1.

Glycolysis block by 2-DG reduces extracellular lactate and lowers proliferation in GBMderived cells. (A) Representative pictures of GBM-derived cells (HuTuP01), plated at medium density (49 cells $\left./ \mathrm{mm}^{2}\right)$ and expanded 1 day (18 hr) in $2 \%$ or $20 \%$ oxygen in the presence of $25 \mathrm{mM}$ glucose or of $25 \mathrm{mM}$ 2-DG (in low glucose medium, containing $2.5 \mathrm{mM}$ glucose). Pictures acquired with an IX50 Olympus inverted microscope; 10X magnification. Bar $=100 \mu \mathrm{m} . \quad(\mathrm{B}, \mathrm{C})$ Extracellular lactate measurement following 2-DG addition, comparing 2 different GBM cell cultures (B) and 3 SVZ-derived cell cultures (C), cultured under 2\% oxygen or $20 \%$ oxygen at the indicated times. $* * *$ p $<0.001$ above $0 \mathrm{hr}$ time point bars indicate statistically significant differences with all the other time points. (D, E) Cell growth kinetics: GBM cells (D) and SVZ cells (E) were plated at medium density (T0 = 49 cells $/ \mathrm{mm}^{2}$ ); cells were either maintained in glucose (solid line) or in 2-DG (dashed line) for 4, 8 and $24 \mathrm{hr}$ at either $2 \%$ (light gray) or transferred to 20\% oxygen (dark grey). Final cell counts $/ \mathrm{mm}^{2}$ were normalized to plating density at T0. Mean of 4 different tumors \pm S.E.M., $\mathrm{n}$ $=3$ for each tumor. Mean of 3 different SVZ cell cultures \pm S.E.M., $n=3$ for each cell culture. (F) Analysis of metabolic activity by MTT assay; cells were cultured under 2\% oxygen or $20 \%$ oxygen and 2-DG was added for 18 or $24 \mathrm{hr}$, values were normalized to cells cultured with glucose at $2 \% \mathrm{O}_{2}$. (G) Intracellular ATP content in GBM cells cultured as described in (F), values normalized to cells cultured with glucose at $2 \% \mathrm{O}_{2}$.

\section{Figure 2.}

Block of glycolysis with 2-DG increases SDH and PDH activity. (A) Representative citochemical analysis (HuTuP13) of SDH activity by using NBT reduction methodology. Cells were incubated for $48 \mathrm{hr}$ in presence of glucose, 2-DG or 3-NPA known to irreversibly inactivate SDH (negative control). (B) Bar graph showing mean percentage of $\mathrm{SDH}^{+}$cells 
(blue-violet cells) counted from 40X magnification pictures (picture area $=0.02 \mathrm{~cm}^{2}$ ), bar $=$ $20 \mu \mathrm{m} .3$ different tumors have been used, $\mathrm{n}=2$ for each tumor. (C, D) Representative western blot analyses (HuTuP36) of pPDH E1 $\alpha$ and total PDH along with $\beta$-actin to control for protein loading. (C) Cells were cultured for $0.5,2,8$ or $18 \mathrm{hr}$ with 2-DG, either left at $2 \%$ oxygen or acutely exposed to $20 \%$ oxygen; the analysis was confirmed using 3 different tumors, $\mathrm{n}=3$ for each tumor. (D, E) Histograms showing percentages of cells with intracellular superoxide anion $\left(\mathrm{O}_{2}{ }^{-}\right)$measured by using hydroethidine (HE), mean \pm S.E.M. from 3 different tumors, $\mathrm{n}=2$ for each tumor.

\section{Figure 3.}

2-DG promotes HIF-1 $\alpha$ degradation, while succinate promotes recovery of HIF-1 $\alpha$ protein level and transcriptional activity in GBM-derived cells. (A) Representative western blot analyses (HuTuP13) of HIF-1 $\alpha$, HIF-2 $\alpha$ and PHD2, along with $\beta$-actin to control for protein loading. GBM-derived cells were initially expanded in $2 \%$, then 2 -DG was added for $0,1,2$, $4,8,18 \mathrm{hr}$, maintaining cells at $2 \%$ or exposing them to $20 \% \mathrm{O}_{2}$. The analyses were confirmed using 3 different tumors, $\mathrm{n}=3$ for each tumor. (B, C) QRT-PCR analyses of HIF$1 \alpha$ and PHD2 normalized to GUSB and then calibrated to $2 \% \mathrm{O}_{2} 0 \mathrm{hr}$ ( $\triangle \Delta \mathrm{Ct}$ Method), mean \pm S.E.M. comparing 3 different GBM, $\mathrm{n}=3$ for each tumor. (D) Representative western blot analyses (HuTuP13) of HIF-1 $\alpha$ and HIF-2 $\alpha$ along with $\beta$-actin to control for protein loading, in GBM derived cells cultured for $18 \mathrm{hr}$ with glucose, 2-DG or diethyl-succinate (5 mM), combined as indicated; to confirm the data 3 different tumors have been used, $\mathrm{n}=2$ for each tumor. (E) HRE-luciferase assay: GBM cells were transiently transfected either with a HREfirefly luciferase reporter construct or with a mutated HRE version of the same construct to evaluate aspecific effects. Along with these vectors, also a Renilla luciferase vector has been 
transfected in order to normalize luciferase detection. Normalization of the data, expressed in RLU (relative light unit), to the mutated HRE vector was done and then values were calibrated to untreated cells (Control). 2 different GBM have been analyzed, $n=3$ for each tumor.

\section{Figure 4.}

Hypoxia inhibits the pro-apoptotic effect caused by 2-DG in GBM-derived cells. (A) Histogram showing percentages of different cell cycle phases in live gated cells based on BrdU and 7-AAD incorporation. GBM-derived cells were cultured as described in Fig. 1A. Mean of 3 tumors \pm S.E.M., $\mathrm{n}=2$ for each tumor. (B) Annexin-V/Propidium Iodide (Annexin-V/PI) staining of GBM derived cells expanded for $0,18,24$ or $48 \mathrm{hr}$ in the presence of $2-\mathrm{DG}$, either at $2 \%$ or $20 \%$ oxygen. Bar graph represents percentages of early apoptotic cells (annexin- $\mathrm{V}^{+} / \mathrm{PI}^{-}$cells) and late apoptotic cells (annexin- $\mathrm{V}^{+} / \mathrm{PI}^{+}$cells); mean of 3 tumors \pm S.E.M., $n=3$ for each tumor. (C) Analysis of mitochondrial membrane potential by using JC-1: histogram shows $\%$ of low $\Delta \psi m t$ in live gated cells (based on physical parameters, side scatter and forward scatter), mean of 2 tumors \pm S.E.M., $\mathrm{n}=3$ for each tumor. (D) Representative western blot analyses (HuTuP15) of Bcl-2, Bcl-XL, PARP, p21 ${ }^{\text {cip1 }}$ along with $\beta$-actin to control for protein loading, in GBM cells cultured for $0,1,2,4,8,18 \mathrm{hr}$ in presence of $2-\mathrm{DG}$, either at $2 \%$ or $20 \%$ oxygen. The analyses were confirmed using 3 different tumors, $\mathrm{n}=3$ for each tumor.

\section{Figure 5.}

2-DG induces neuronal commitment and addition of succinate antagonizes this effect by reducing GBM differentiation. (A) Histogram showing percentages of CD133 ${ }^{+}$, mean of 4 tumors \pm S.E.M., $n=3$ for each tumor. (B-D) histograms showing respectively nestin, GFAP 


\section{Figure 6}

Summary of the principal effects elicited by 2-DG, succinate and oxygen tension in GBM cells. (Left part) Under hypoxia GBM cells display high anaerobic glycolysis, low PDH (i.e. phosphorylated PDH) and low SDH activity, the latter causative of intra-cytoplasmic accumulation of succinate and consequentially also of ROS. Both ROS and succinate have been described as inhibitors of PHDs activation, causing the stabilization of HIF-1 $\alpha$. Addition of succinate elicits analogous effects, as shown by HIF-1 $\alpha$ stabilization and increased number of GBM stem cells. (Right part) Addition of 2-DG associate to exposure to $20 \% \mathrm{O}_{2}$ increase PDH activity (i.e. de-phosphorylated PDH) and consequentially SDH activity, thus intracellular succinate and mitochondrial ROS release are reduced, according to literature. As a consequence PHD2 activity increases, HIF-1 $\alpha$ is poly-ubiquitylated and consequentially degraded, which correlates with the acquisition of a more committed phenotype, according to previous works. Under these circumstances GBM cells undergo more rapidly apoptosis. Importantly, all these effects are mitigated by the hypoxia and by addition of succinate, which prevent SDH activity and tumor cell differentiation induced by 2-DG. 
Figure 1
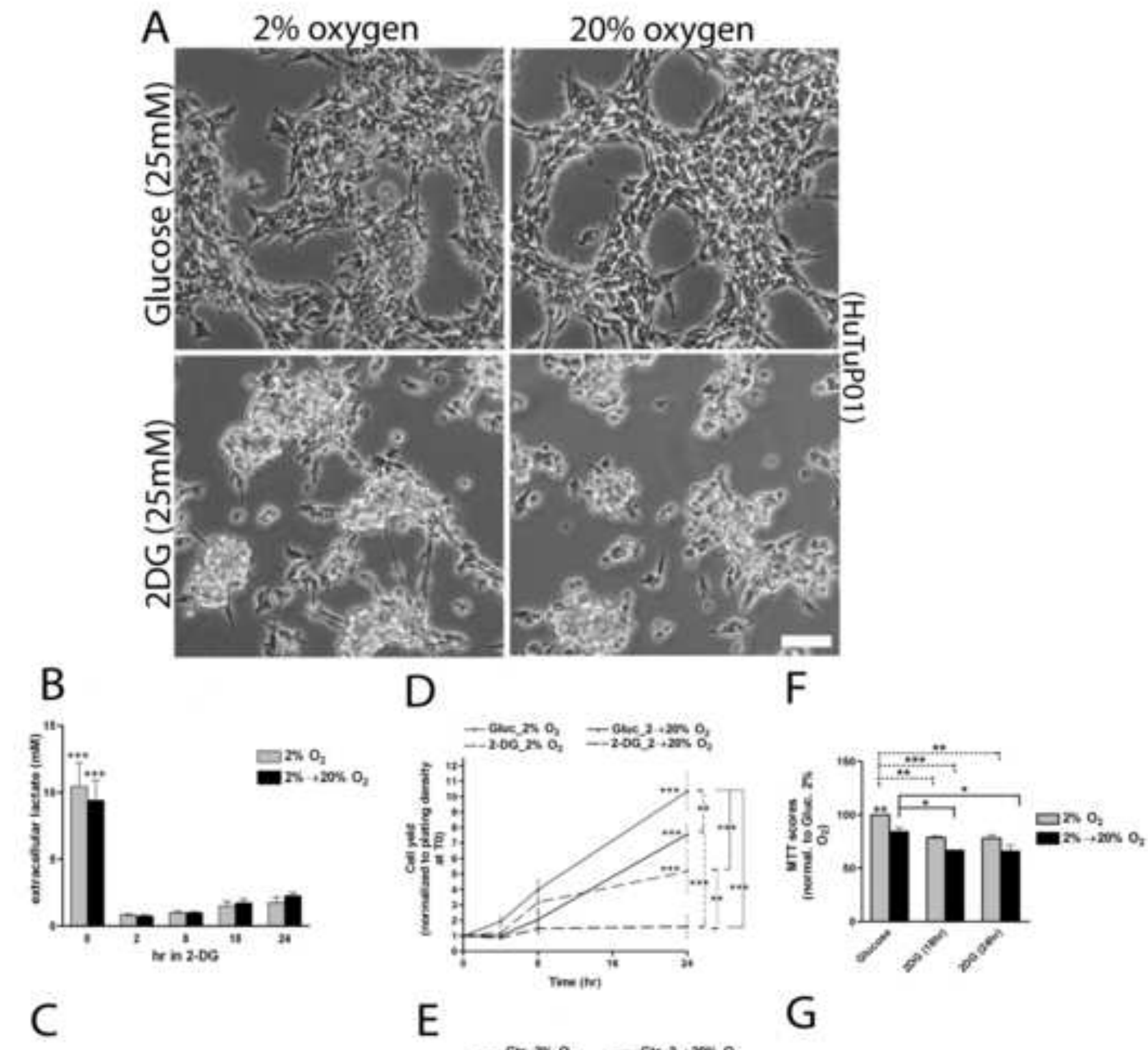

E
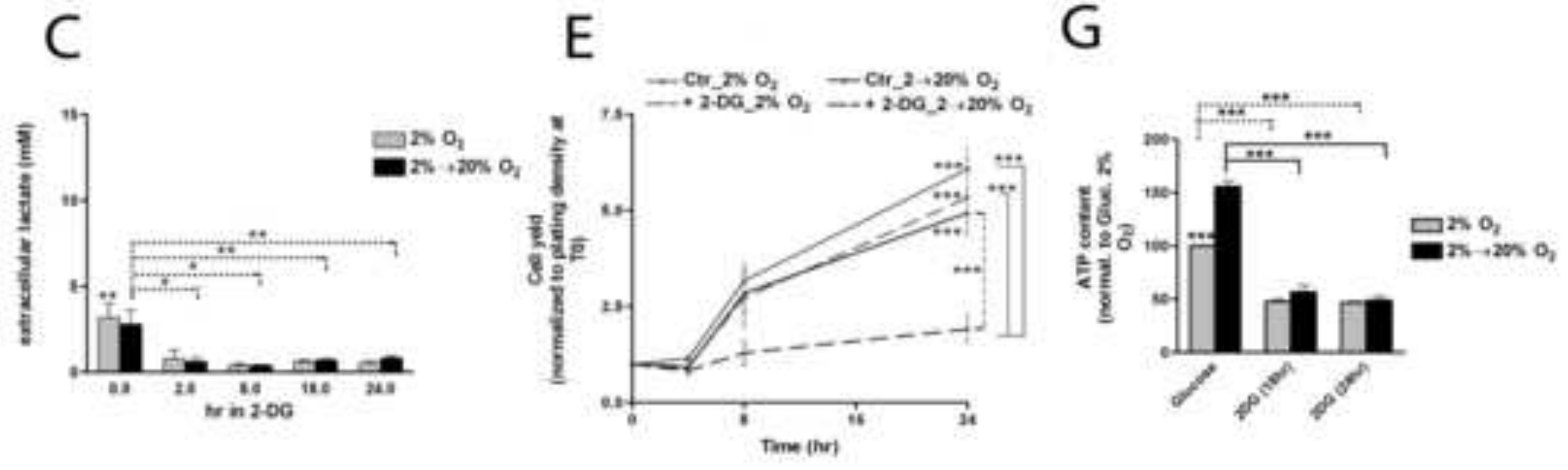
Figure 2

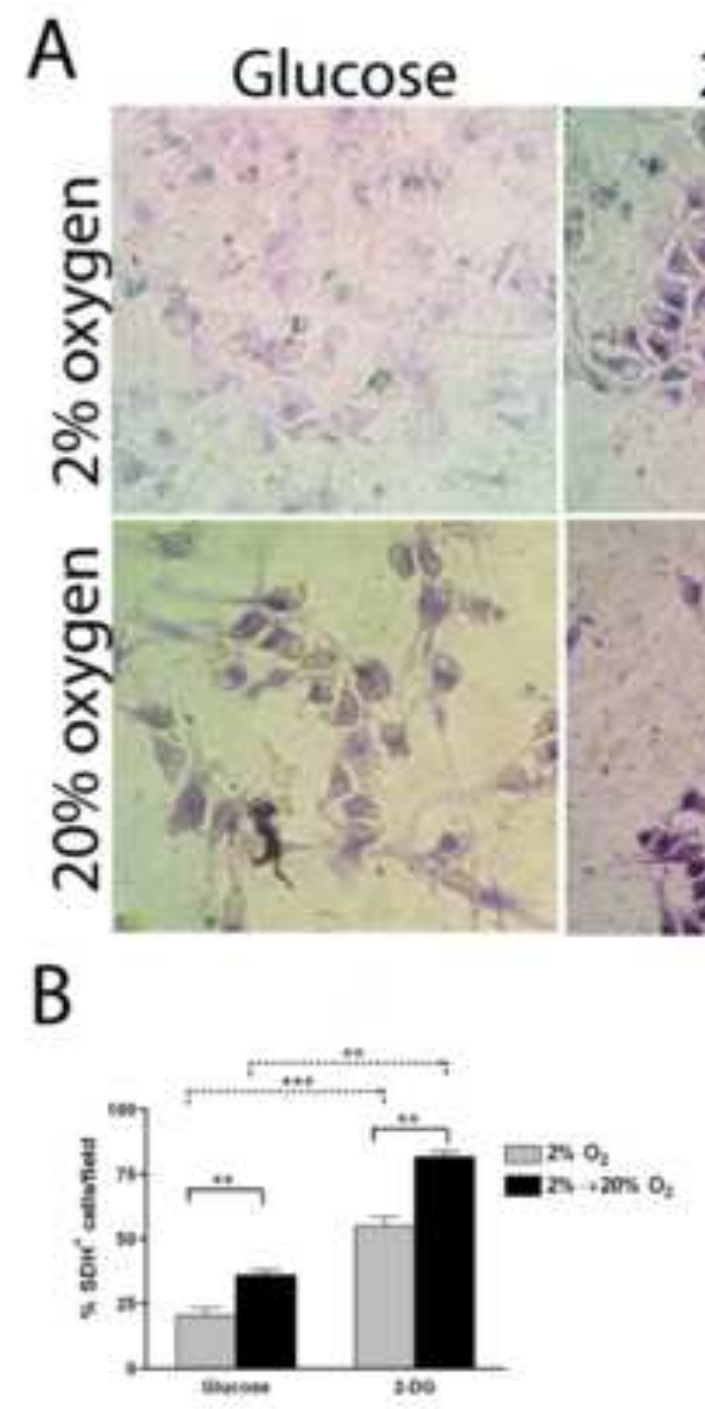

D
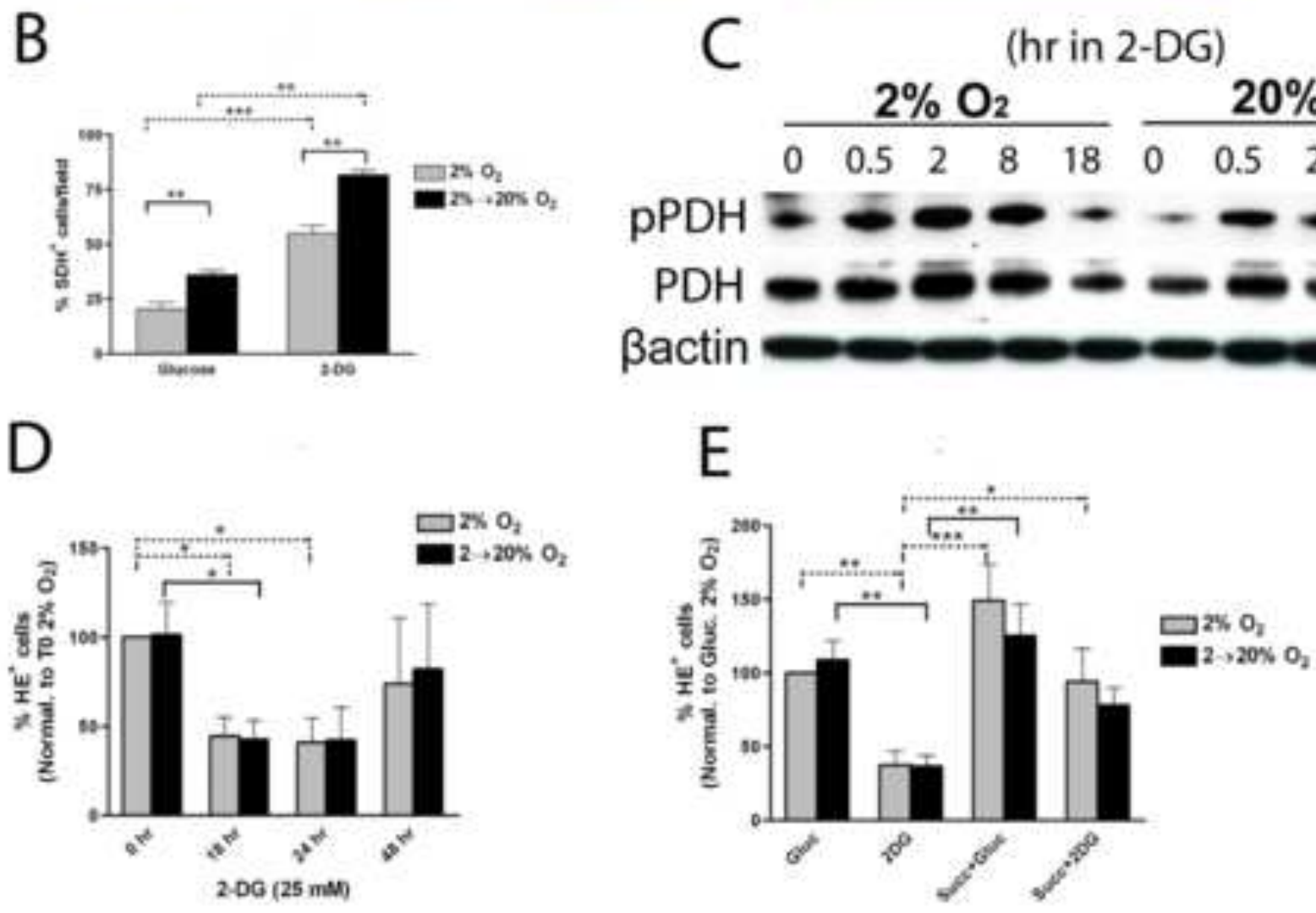
Figure 3

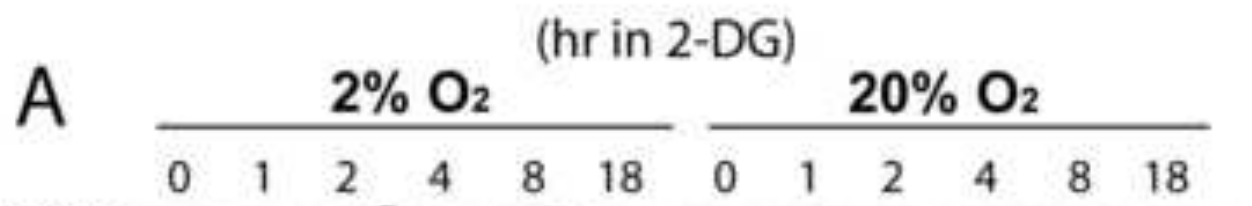

poly-ubiq.HIF 1a

HIF1a

HIF2a

PHD2

Bactin

B

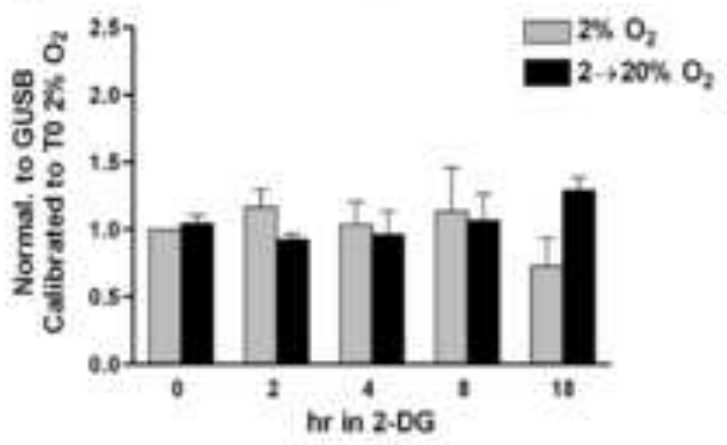

C

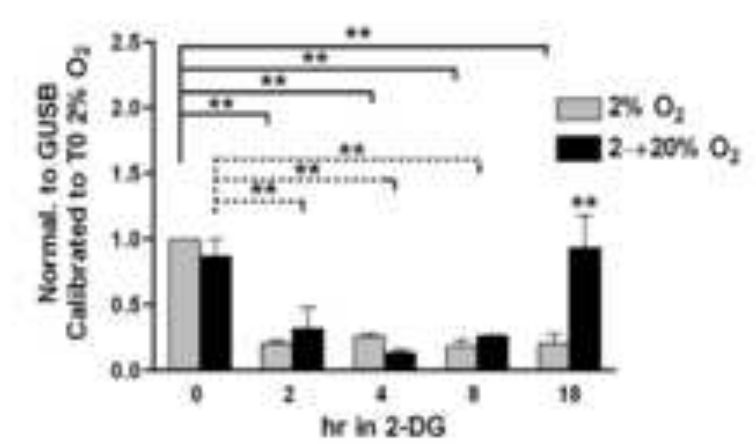

D

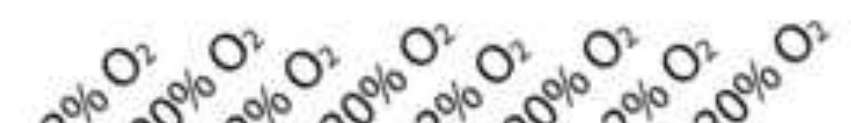

$$
\begin{aligned}
& ++++-\cdot-\text { Glucose } \\
& -\quad-++++2 \text {-DG } \\
& -++-{ }_{-}+\text {Succinate }
\end{aligned}
$$

HIF1a

HIF2a

단

ßactin
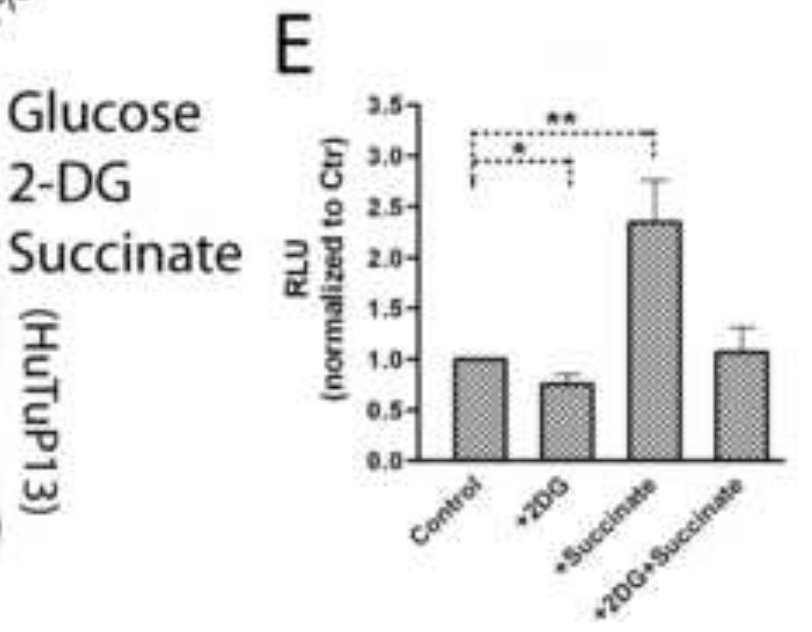
Figure 4

A

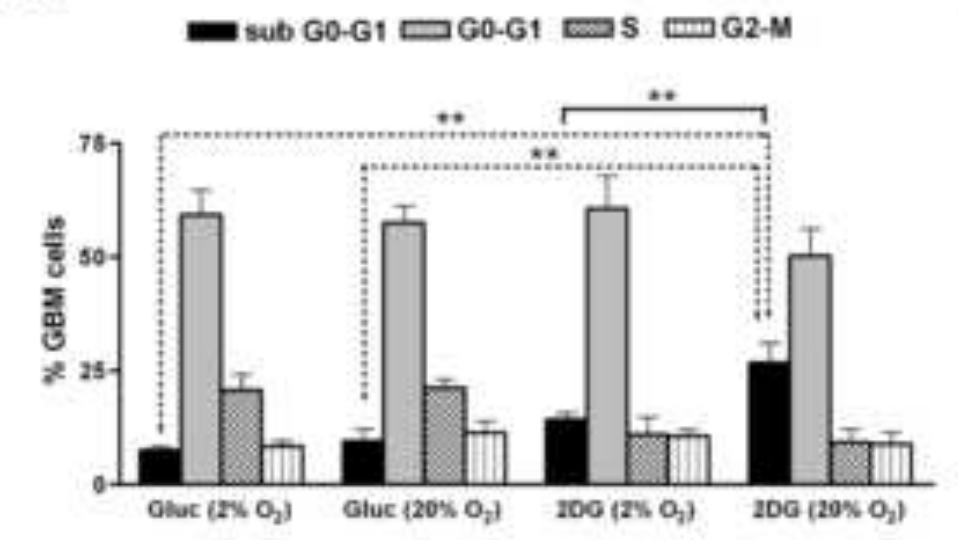

C

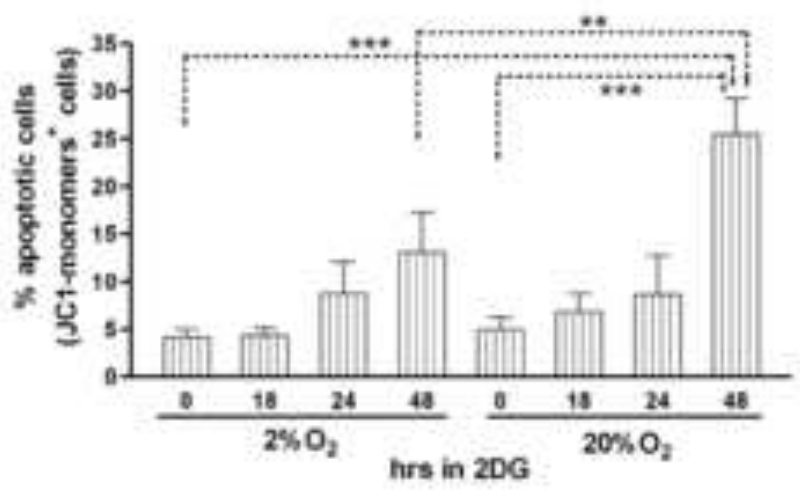

B

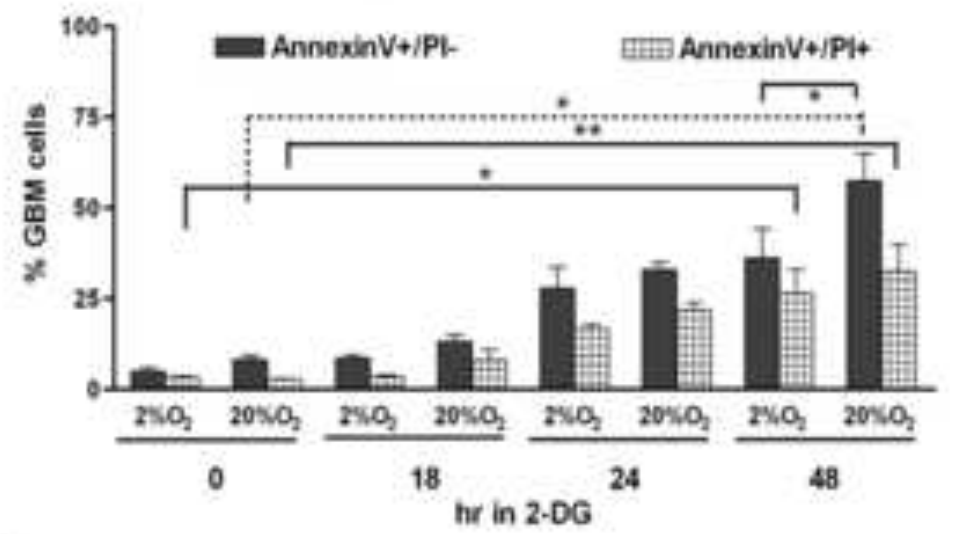

D

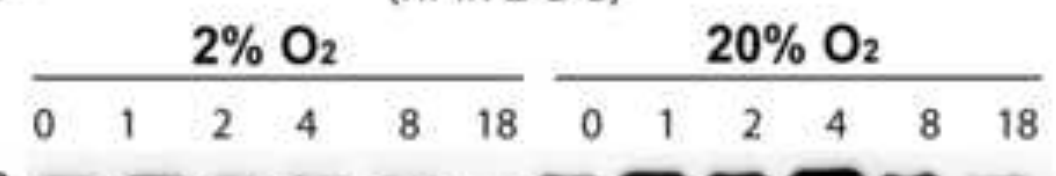

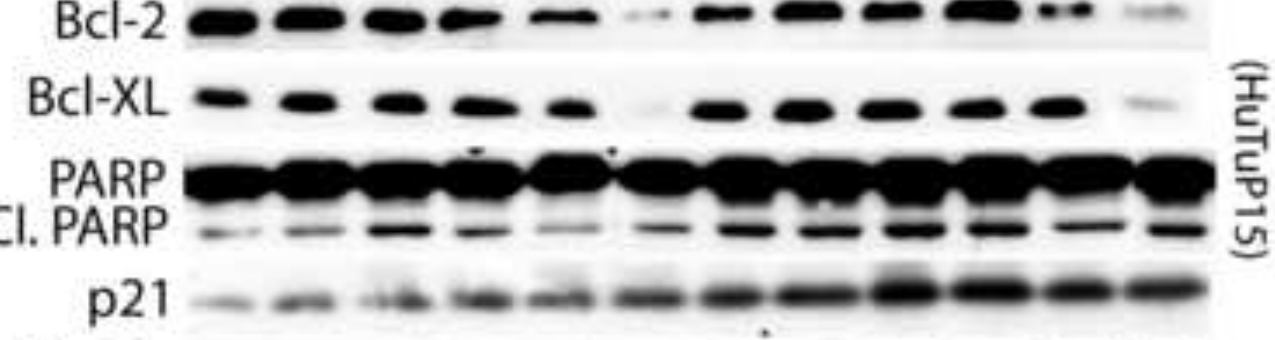
Bactin - - - - - - - - 
Figure 5

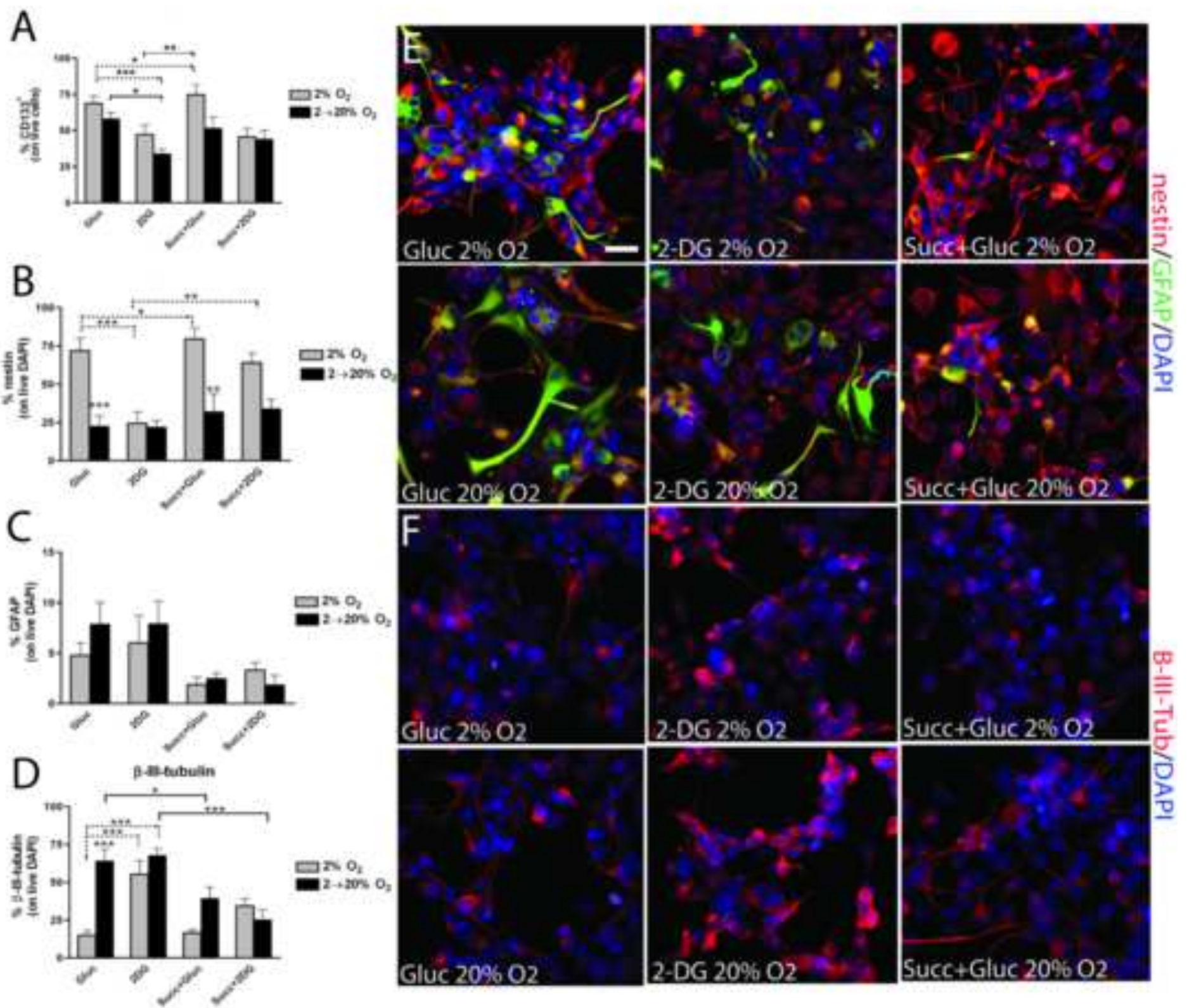


Figure 6

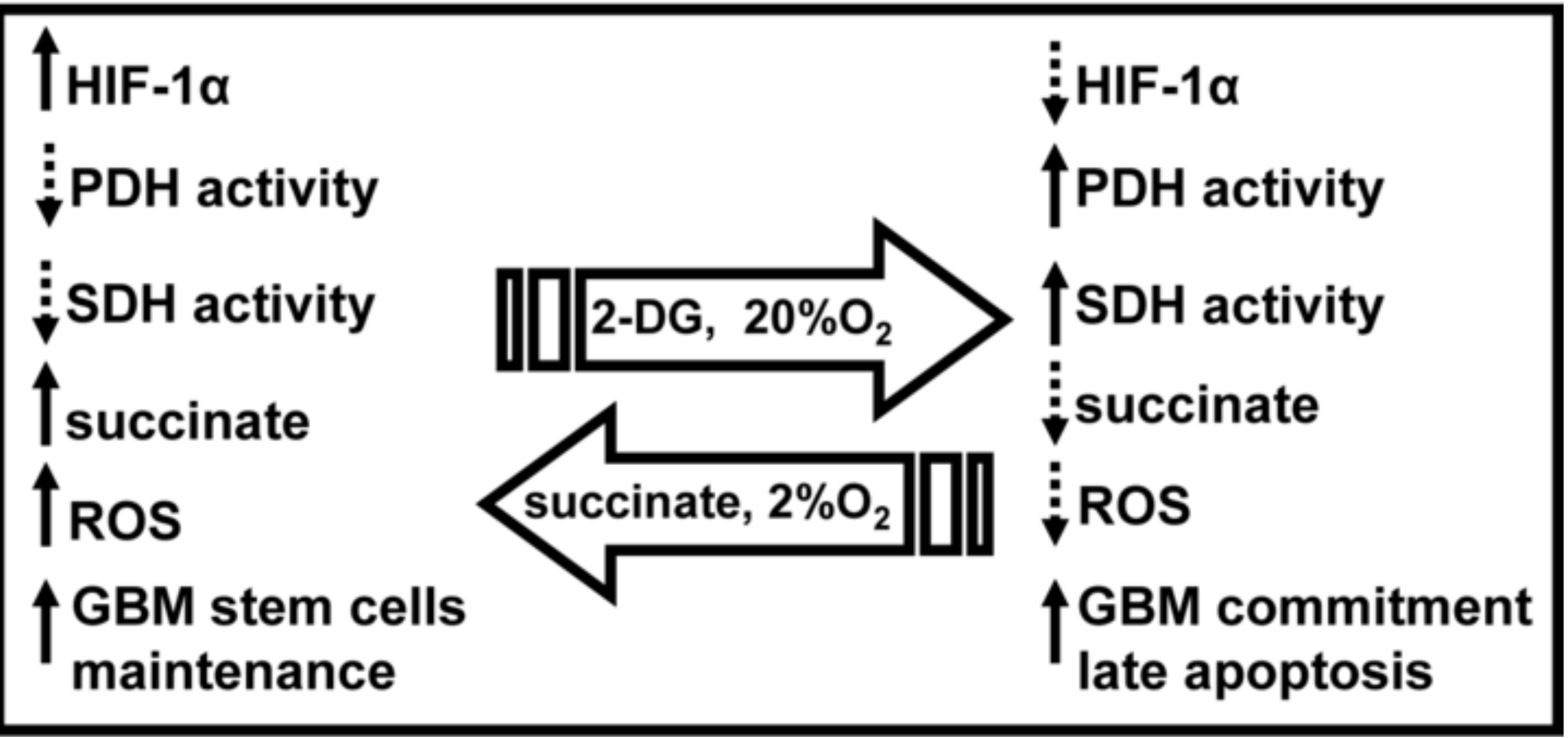




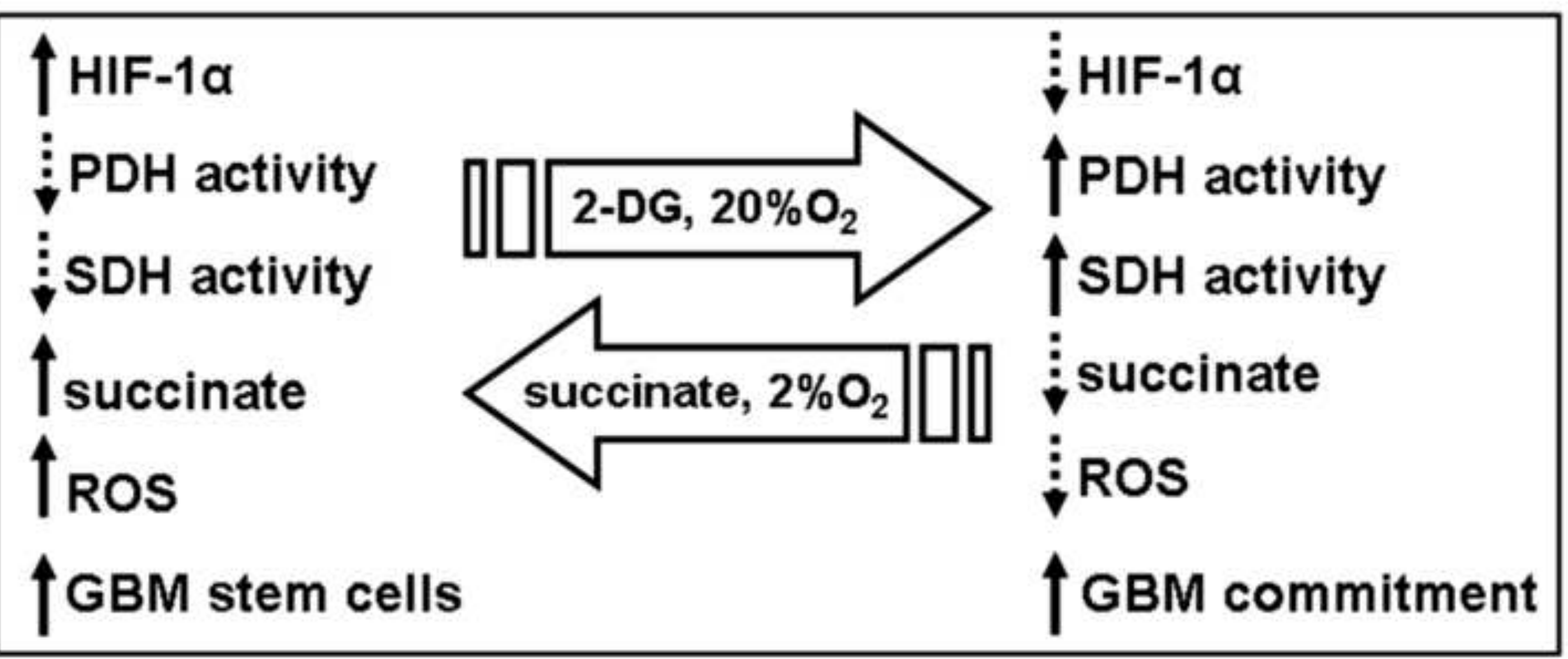

\section{Effects of 2-DG, succinate and oxygen tension in \\ Glioblastoma (GMB) cells}

